\title{
Quo vadis Aethina tumida? Biology and control of small hive beetles
}

\author{
Peter NeumanN ${ }^{1,2,3}$, Jeff S. Pettis ${ }^{4}$, Marc O. SchäFer ${ }^{5}$ \\ ${ }^{1}$ Institute of Bee Health, Vetsuisse Faculty, University of Bern, Bern, Switzerland \\ ${ }^{2}$ Swiss Bee Research Centre, Agroscope, Bern, Switzerland \\ ${ }^{3}$ Social Insect Research Group, Department of Zoology \& Entomology, University of Pretoria, Pretoria, South Africa \\ ${ }^{4}$ Bee Research Laboratory, USDA-ARS, Beltsville, MD, USA \\ ${ }^{5}$ National Reference Laboratory for Bee Diseases, Friedrich-Loeffler-Institute (FLI), Federal Research Institute for \\ Animal Health, Greifswald, Insel-Riems, Germany
}

Received 15 June 2015 - Revised 8 November 2015 - Accepted 30 December 2015

\begin{abstract}
Small hive beetles (SHBs) are generalists native to sub-Saharan Africa and reproduce in association with honeybees, bumblebees, stingless bees, fruits and meat. The SHB has recently become an invasive species, and introductions have been recorded from America, Australia, Europe and Asia since 1996. While SHBs are usually considered a minor pest in Africa, they can cause significant damage to social bee colonies in their new ranges. Potential reasons for differential impact include differences in bee behaviour, climate and release from natural enemies. Here, we provide an overview on biology, distribution, pest status, diagnosis, control and prevention to foster adequate mitigation and stimulate future research. SHBs have become a global threat to both apiculture and wild bee populations, but our knowledge of this pest is still limited, creating demand for more research in all areas of its biology.
\end{abstract}

\section{Apis mellifera / Aethina tumida / bees / invasive species / small hive beetle}

\section{INTRODUCTION}

In recent decades, the frequency of biological invasions and their impact on both agriculture and natural ecosystems have increased to an unprecedented level, thereby stimulating a multitude of research projects (Nentwig 2007). The small hive beetle (SHB), Aethina tumida (Coleoptera: Nitidulidae; Figure 1) constitutes an example of such an invasive species, and it can have a significant impact on apiculture as well as on wild and feral bee populations. Prior to 1998, there was only very limited knowledge of SHB (reviewed by Hepburn and Radloff 1998). This has changed

Corresponding author: P. Neumann, peter.neumann@vetsuisse.unibe.ch Handling Editor: Yves Le Conte dramatically since the first significant damage to apiculture was noted outside its endemic range (cf. Neumann and Elzen 2004). Here, we review the recent literature on the SHB. Please refer to Hood (2004), Neumann and Elzen (2004), Ellis and Munn (2005), Calderón Fallas et al. (2006) and Ellis and Hepburn (2006) as sources of references up to December 2005. We will focus on examining the more proximate aspects of the biology of the beetle as well as on diagnosis and control, which is crucial to understand the invasion process and to mitigate its consequences.

\section{THE LIFE CYCLE OF SMALL HIVE BEETLES}

The SHB belongs to the coleopteran family Nitidulidae, which consists of $>2500$ described species globally (Habeck 2002). Nitidulid beetles can reproduce on a large variety of different food 


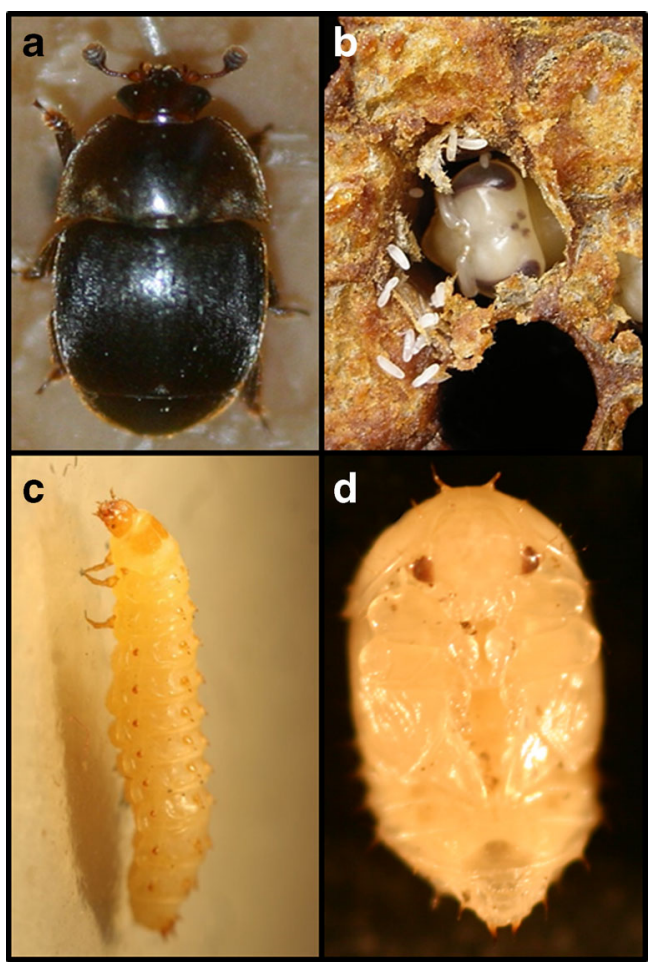

Figure 1. Small hive beetle life stages. a Adult: 5-7$\mathrm{mm}$ long and 2.5-3.5-mm wide, characteristic "clubshaped" antennae, short elytra (wing buds) $=$ abdomen is exposed (picture: Nelles Ruppert). b Eggs laid in capped honeybee worker brood: creamy white, about $1 / 3$ the size of honeybee eggs (picture: M. Schäfer). c Wandering larvae: $\sim 1-\mathrm{cm}$ long, creamy white, three pairs of long forelegs, a row of spines on the dorsal side of each body segment and two large spines protruding from the rear (picture: M. Schäfer). d Pupae: creamy white to light brown, $\sim 5-\mathrm{mm}$ long (picture: Anna Röttger).

sources, mostly of plant origin and most often after fungal invasion, such as trees with fungi, fresh, rotten and dried fruits and grain, plant fermented juices; however, many Nitidulids are associated with flowers and very rarely with mining of leaves, carrion and crops (Kirejtshuk 1994a, b, 1997; cf. Neumann and Elzen 2004). While some Aethina species visit and develop in blooming plants (mainly anthophagous species of the subgenus Circopes Motschoulsky 1858, e.g. Aethina concolor, Buchholz et al. 2008), others are feeding on fungi (mycetophagous, e.g. Aethina suturalis, Park et al. 2014), but most of them are connected with a variety of decaying substrates of plant origin (Kirejtshuk 1994a, b, 1997; Kirejtshuk and Lawrence 1999). It is therefore not surprising that SHB can also exploit a range of different food sources for maintenance and reproduction. Here, we focus on aspects necessary to control the beetle; other features on morphology and natural history are reported in more detail elsewhere (Lundie 1940; Schmolke 1974; Hepburn and Radloff 1998; cf. Hood 2004; cf. Neumann and Elzen 2004). An overview of the SHB life cycle and of the biotic and abiotic factors influencing adult beetle maintenance and reproduction is given in Table I and Figures 2 and 3. In brief, adult SHBs emerging from the soil can infest colonies of social bees as individuals or swarms (Neumann and Elzen 2004; see Figure 3 and Table II). Alternatively, but not mutually exclusive, SHBs can utilize food sources outside of colonies. Both inside and outside of colonies, adult SHB can maintain themselves and reproduce. When SHB larvae have reached the post-feeding, so-called wandering stage, they leave the food sources for pupation in the soil. After pupation, adult SHBs leave the soil to complete their life cycle.

Evidence has emerged that various factors can impact the survival and reproduction of SHBs (Figure 2): Intraspecific factors are competition for food (Meikle et al. 2012), cannibalism (both adults and perhaps larvae can eat dead and weaker conspecifics and eggs; Neumann et al. 2001b), multiple mating (both males and females have been observed to copulate multiple times; J. Pettis and P. Neumann, unpublished observations; Mustafa 2015, but genetic evidence for polyandry is lacking), aggregation of adults (Neumann and Elzen 2004; Spiewok et al. 2007; Mustafa et al. 2006; Torto et al. 2010a; Mustafa 2015) and larvae (on combs and in corners of brood box; Hood 2011). Interspecific biotic factors include interactions with adult and immature host bees (cf. Neumann and Elzen 2004; Neumann et al. 2013; Pirk and Neumann 2013), human activity (e.g. IPM; Ellis 2005a, b; Hood 2011), low sanitation in honey houses 
Table I. Small hive beetle life stages.

\begin{tabular}{lll}
\hline Life stage & Duration & Comments \\
\hline Adults & $\begin{array}{c}\text { 1-12, probably up to 16 months in } \\
\text { laboratories (Somerville 2003) }\end{array}$ & $\begin{array}{c}\text { Females die quickly when ovipositing } \\
\text { on a daily basis } \\
\text { Optimal humidity of }>65 \% \text { and }>30^{\circ} \mathrm{C} \text { leads to rapid } \\
\text { egg hatch in as little as } 24 \mathrm{~h} \text {; relative humidity of } 34 \% \\
\text { prevented egg survival (Annand 2011b) }\end{array}$ \\
$\begin{array}{ll}\text { Feeding larvae } \\
\text { Wandering larvae } 3 \text { days }\end{array}$ & $\begin{array}{c}\text { May live for up to 61 days without } \\
\text { food (Meikle and Diaz 2012) }\end{array}$ & $\begin{array}{c}\text { Aggregating larvae have been observed to stay } \\
\text { in colonies for more than 20 days prior to } \\
\text { moving to soil }\end{array}$ \\
Pupae & 13 to 25 days & $\begin{array}{c}\text { Temperature and soil moisture and type } \\
\text { determine length of pupation }\end{array}$ \\
\hline
\end{tabular}

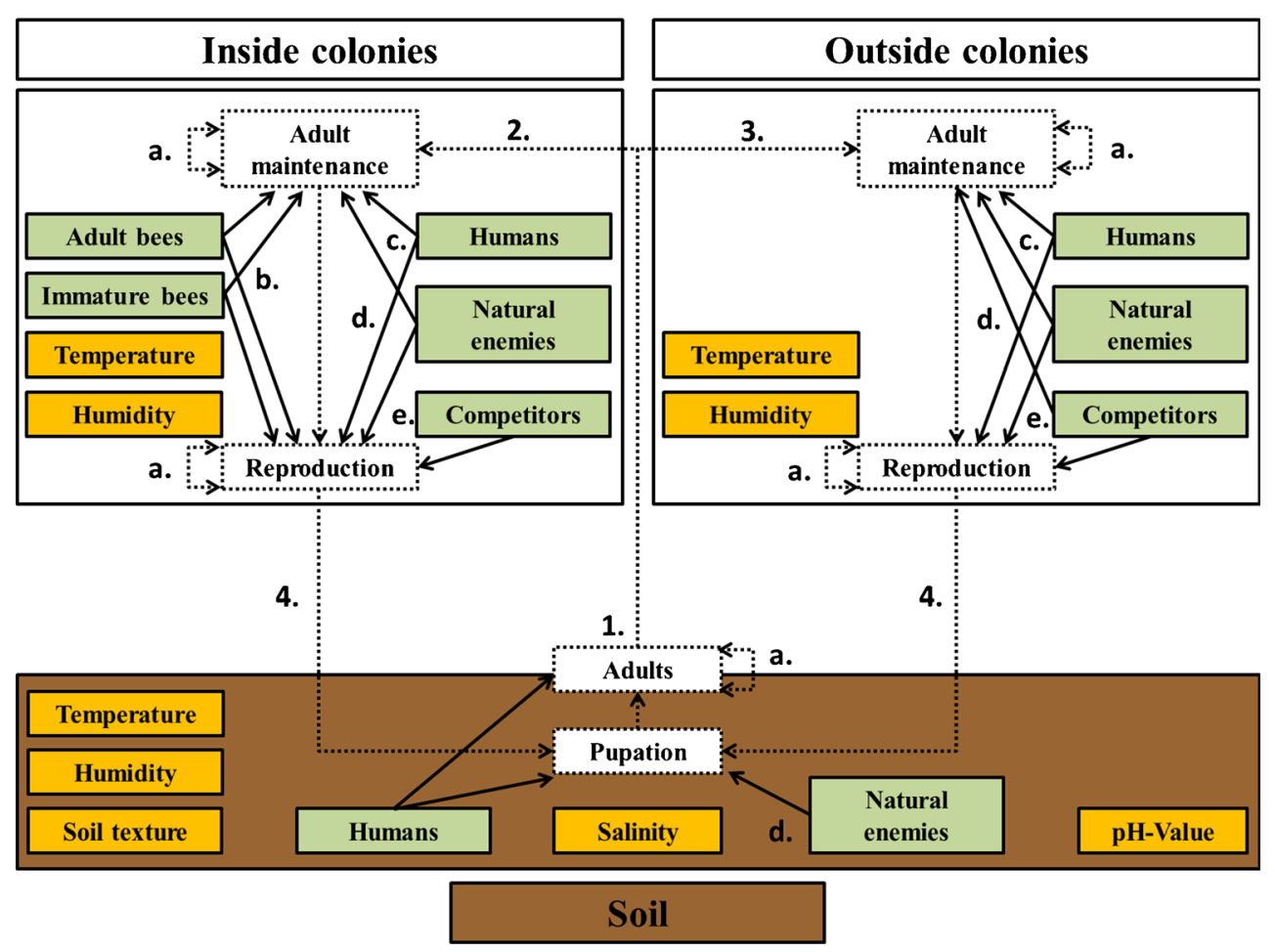

Figure 2. Life cycle of the small hive beetle (SHB). Adult maintenance and reproduction (dotted lines and dotted boxes ) occur inside and outside of social bee colonies and pupation in the soil (dark brown). Biotic factors (green boxes) and abiotic factors (orange boxes) can impact SHB survival and reproduction. Adult SHBs emerging from the soil (1 .) infest colonies of social bees (2.) as individuals or swarms or approach food sources outside of colonies (3.), where they feed and reproduce. Then, wandering larvae leave the food sources for pupation in the soil (4.). After pupation, adult SHBs leave the soil and close the life cycle. Biotic factors such as intraspecific SHB interactions (dotted lines; $a$.), interspecific interactions (solid lines) with adult and immature host bees $(b$.), humans $(c$.$) , natural enemies (d$. ) and competitors $(e$. ) as well as abiotic factors (temperature, humidity, soil texture, salinity, $\mathrm{pH}$ value) can enhance or limit SHB survival and reproduction. 


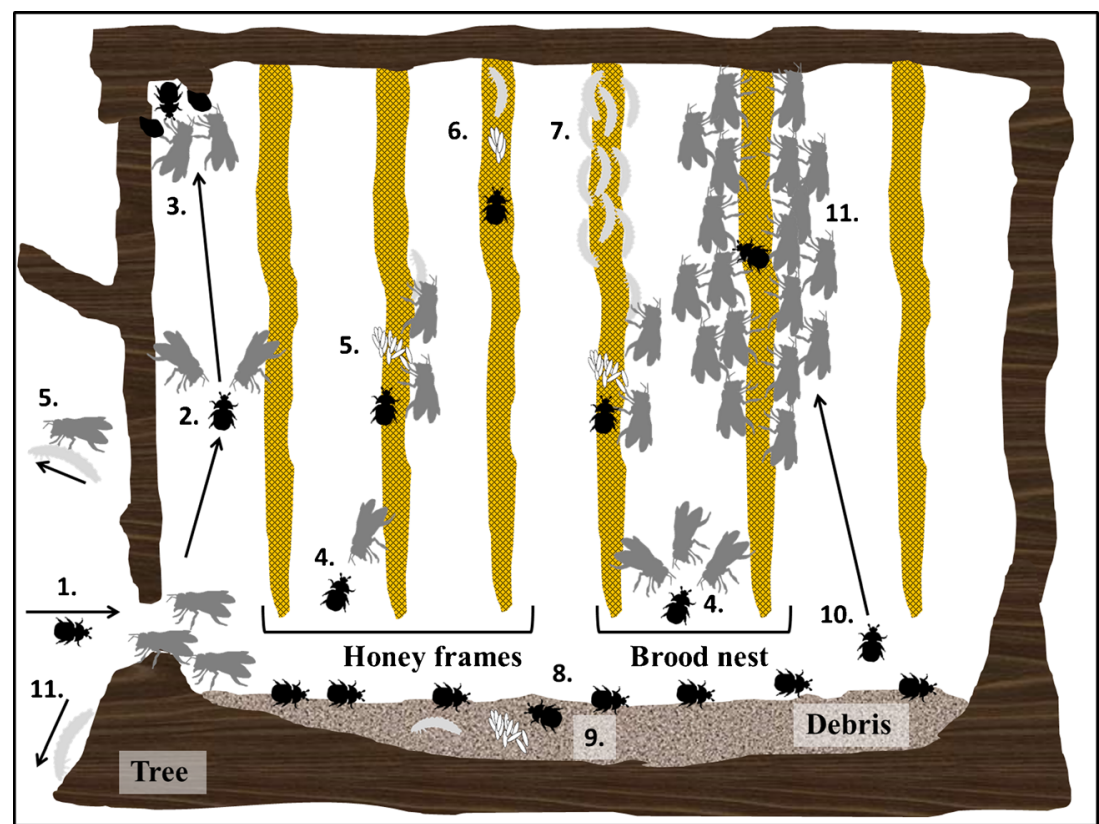

Figure 3. Schematic overview of small hive beetle (SHB) infestation of a virtual honeybee nest in a tree with honey frames, brood nest and debris. An overview of behavioural interactions between host bees and SHBs is given: 1 . SHB intrudes vs. guard bees (first line of colony defence); 2 . SHBs roam and bees attack in the colony; 3 . SHBs retreat into hiding, bees guard, feed SHBs and build prisons; 4 . SHBs try to intrude honey frames and/or brood nest for food and reproduction and patrolling bees intercept SHBs (second line of colony defence); 5 . Intruded SHBs lay eggs on frames and bees eat eggs, remove/kill larvae and carry larvae out of colony (third line of colony defence). 6 . Cryptic SHB reproduction in sealed honeycomb; 7. SHB destructive mass reproduction $=$ colony defence failed or absent; 8 . Majority of adult SHBs on the bottom; 9 . SHBs feed and reproduce in debris. 10. During cooler weather, SHBs get closer into nest. 11 . Overwintering in winter cluster, bees both feed and attack beetle. Arrows indicate movement directions (SHB: black irregular $=$ adult, light grey $=$ larva, white ovals $=$ eggs; dark grey irregulars $=$ honeybee workers; black oval = propolis). Please note that events are not simultaneous, e.g. 7. and 11.

(Spiewok et al. 2007), natural enemies (e.g. Buchholz et al. 2008; Arbogast et al. 2010) and competitors (e.g. wax moth (Spiewok et al. 2006b) or fruit flies (Buchholz et al. 2008). Abiotic factors are temperature, texture, salinity, $\mathrm{pH}$ value and humidity, particularly during pupation (Ellis et al. 2004d; Meikle and Diaz 2012).

\subsection{Inside colonies}

Nests of social bees not only provide comparatively rich food resources for SHBs but also protection from a range of environmental hazards (Michener 1974; Hepburn and Radloff 1998), e.g. almost half of the SHB population (44\%) was recorded outside hives during hot months, but during cooler times, SHB populations were predominantly within hives (Annand 2011b). However, in such nests, SHBs are facing defences from the host workers (Figure 3), thereby resulting in a trade-off scenario between highly rewarding food and the danger of injury. Therefore, it appears as if behavioural interactions between host bees and SHBs (Tables II and III) are of prime importance to understand the biology of $A$. tumida .

\subsubsection{Apis spp.}

It is well established that SHBs can maintain themselves and reproduce in colonies of African (Lundie 1940), Africanized (Loza et al. 2014) and 
Table II. Overview of small hive beetle behaviours. Please refer to Neumann and Elzen (2004) and Neumann et al. (2013) for further references. A brief description is provided.

Adults

Behaviour

Description

Flying

Host colony finding

Host colony intrusion

Aggregation

Hiding

Mating

Turtle defence posture

Walking

Running

Flee

Dropping from frame

Antennating with a SHB

Antennating with worker

Trophallactic contact

Interfering with other SHB trophallactic contact

Oviposition

Feeding

Mount a bee
Actively flying. Accurate estimates of speed and maximum possible distance are lacking so far

Detection of host colonies, possibly under stress (disease, management) from a distance of $\sim 13-16 \mathrm{~km}$

Intrusion of strong colonies as well as weak ones with equal impunity

Flying as swarms and non-random distribution among infested colonies (not correlated with colonial phenotypes, Spiewok et al. 2007). Aggregating inside infested hives (Spiewok et al. 2007), especially on bottom boards (Neumann and Hoffmann 2008; Torto et al. 2010b). Attractions of adults to each other (Mustafa et al. 2006) and mating in aggregations (Mustafa 2015), but possible cues are unknown (pheromones?)

In small cracks, under bottom boards or in cells. During inspections, adult SHB are quickly moving from one hiding place to another one nearby.

Males mount females, then copulation occurs, both males and females may mate multiple times and SHBs only copulate in aggregations and sexual behaviours reaches its peak at the ages from 2 to 3 weeks (Mustafa 2015)

Attacked SHB retreat head underneath pronotum, press antennae and legs tightly to the body

Moving around $(<5 \mathrm{~mm} / \mathrm{s}$ without being chased by a SHB or worker)

Moving fast ( $>5-10 \mathrm{~mm} / \mathrm{s}$ ), without being chased by a SHB or worker

Moving fast ( $>5-10 \mathrm{~mm} / \mathrm{s}$ ), while being chased by (a) a fellow SHB,

(b) by a worker and (c) by more than one worker

Deliberately dropping from combs to escape pursuit by (a) a fellow SHB,

(b) by a worker and (c) by more than one worker

Antennal contact with one or more SHB

Antennal contact with any bee (e.g. with a guard bee at a confinement site or prison, Ellis 2005c)

Obtaining a drop of food from an adult honeybee worker that is presenting food between its mandibles (Ellis et al. 2002d), which is innate and success increases with experience (Neumann et al. 2015)

Obtaining food while another SHB gets fed, similar to Braula coeca (Neumann et al. 2015)

In batches (10-30 plus, Stedman 2006) in nests of Apis mellifera: cracks and crevices, cells with pollen cells preferred, underneath sealed brood cells (Ellis et al. 2003a, e; Ellis and Delaplane 2008a, b); Bombus impatiens nests: attached to brood pots (Hoffmann et al. 2008); on fruits (Buchholz et al. 2008), and on decaying meat (Buchholz et al. 2008); Oviposition can be stimulated by proteins (pollen and yeast) in SHB diet (Haque and Levot 2005)

Feeding on (a) pollen, (b) honey/nectar, (c) honeybee larvae, (d) a dead honeybee, (e) a dead conspecific SHB, (f) a freshly emerged live honeybee worker (Pirk and Neumann 2013) and (g) fruits (Buchholz et al. 2008)

Mounting a honeybee workers' abdomen and cutting with the mandibles

through the tissue between the tergites 
Table II (continued)

Adults

\begin{tabular}{ll}
\hline Behaviour & Description \\
\hline $\begin{array}{l}\text { Larvae } \\
\text { Behaviour } \\
\text { Phototaxis }\end{array}$ & Description \\
& Feeding phase: negative; wandering phase: positive and \\
Mining & negative once in soil (P. Neumann, unpublished data) \\
& Larvae mine sealed combs similar to wax moth larvae (Neumann \\
Feeding choice & and Hoffmann 2008) \\
Feeding & Migration towards preferred food stuff (Buchholz et al. 2008) \\
& Feeding on (a) pollen, (b) honey/nectar, (c) honeybee larvae, \\
& (d) a dead honeybee, (e) alive or dead conspecific eggs, larvae or \\
& adult SHBs (P. Neumann, K. Merkel, D. Hoffmann, J. Pettis, \\
& unpublished data; but see Meikle et al. 2012), (f) fruits \\
& (Keller 2002; Buchholz et al. 2008) and (g) beef schnitzel (Buchholz et al. 2008). \\
Wandering larvae leave food source for pupation in the soil singly & Accumulating on combs or in corners of infested hives \\
Migration & (Hood 2011) or mass migration out of hives (P. Neumann, \\
Aggregation & unpublished observations)
\end{tabular}

European honeybees, Apis mellifera (cf. Neumann and Elzen 2004). SHBs were also found in Apis cerana colonies in the Cairns area of Australia (an established incursion, as this species is not endemic there) but is no longer monitored for (R. Spooner-Hart, personal communication). However, it is currently unknown what the potential impact on the other cavity nesting or open nesting species will be. So far, besides Australia, there is also an overlap between SHBs and Apis florea in Africa (Bezabih et al. 2014) and recently with other Apis species in Asia (Brion 2015; see Figure 4), but to date, there is no information available on the potential impact of SHBs on these other Apis species.

In contrast to African honeybee subspecies, even strong colonies of European honeybee subspecies can be taken over and killed by SHBs within less than 2 weeks (Neumann et al. 2010). Thus, successful SHB reproduction seems to be more common in strong European colonies compared to African ones. Even though the SHB larvae are the most destructive life stage, the presence of adult SHBs also reduces flight activity in Western honeybees (Ellis et al. 2003b; Ellis and
Delaplane 2008a). Differences between honeybees of European origin have been reported in the USA, with higher mortality of colonies of Italian origin compared to those with a Russian origin in October, when SHB peak infestations were observed (de Guzman et al. 2006, 2010). However, Russian and Italian bees did not differ significantly with respect to detection and removal of brood infested with eggs and larvae of SHBs (de Guzman et al. 2008).

Tug of war: interactions between host bees and small hive beetles An overview of SHB and host bee behaviours is given in Figure 3 as well as in Tables II and III. Colonies can rely on three lines of defence:

First line of defence: guard bees at the hive entrance

Although SHBs usually invade weak and strong colonies with equal impunity (Lundie 1940), fewer adult SHBs were reported from colonies with modified entrances (Ellis et al. 2002a). This suggests that guard bees can, in principal, limit SHB invasion (Figure 3). 
Table III. Overview of honeybee behaviours towards small hive beetles. Please refer to Neumann and Elzen (2004) and Neumann et al. (2013) for further references. A brief description is provided.

Behaviour Description

Aggression

Guarding

"Corralling"

Social encapsulation

Trophallactic feeding

Patrolling

Removal of eggs

Removal of larvae

Absconding
Workers attack both the adults and larvae trying to bite or sting, but usually with only little success for SHB adults ( $<1 \%$ Neumann et al. 2015). However, risk of SHB injury is not zero (decapitation and/or extremities removed)

Fewer SHB intruded colonies with reduced entrances, suggesting that guard bees can limit SHB intrusion

SHB are confined into specific corners, preventing them from moving freely over the combs

SHBs are often encapsulated in propolis confinements. While some workers add propolis around detected hidden or corralled SHB and can completely encapsulate them, others are continuously guarding (Ellis et al. 2004a, b, c)

See Table II

Only few SHB can be seen on the combs of strong colonies, indicating that such colonies are able to prevent SHB intrusion in the comb area at least to some degree by guarding this area. This comb-guarding behaviour (patrolling) seems to be more efficient in strong colonies due to the higher density of bees in the nest and particularly well expressed in the brood area of the colony but less well expressed in the outer frames and honey supers (Spiewok et al. 2007). This might explain why adult beetles may oviposit on outer frames and why larvae can appear on them after transport to the honey house. It appears as if the host becomes alerted by newly intruded beetles

SHB eggs are eaten by workers (Neumann and Härtel 2004), both protected underneath cell cappings (Ellis et al. 2003a, e) or in gaps and unprotected ones

Workers can carry larvae out of the hive at some distance

(Neumann and Härtel 2004). Appears to be efficient in strong colonies

When heavily infested with SHBs, both African and European honeybee colonies abscond (Hepburn and Radloff 1998; Villa 2004)
Thus, efficacy of African guard bees to intercept SHB might be enhanced, not only because they can be more aggressive towards SHB (cf. Neumann and Elzen 2004) but also because those subspecies use ample propolis to limit the size of the entrance and chances of colony invasion (Hepburn and Radloff 1998). The Cape honeybee, A pis mellifera capensis, exhibits a unique fan-blowing behaviour to repel ants at the nest entrance, but SHB adults were removed by mauling and expulsion (Yang et al. 2010). In Australia, the greatest number of SHBs entered hives in the $2 \mathrm{~h}$ prior to nightfall (Annand 2011b), which is in line with earlier reports of activity at dusk (cf. Neumann and Elzen 2004).
Second line of defence: host workers patrolling the nest and guarding combs

The protection of combs (patrolling behaviour) seems particularly well expressed in the brood area of the colony but less well expressed in the outer frames and honey supers (Schmolke 1974; Solbrig 2001; Figure 3). In colonies, SHB distribution is influenced by the presence of bees with more SHBs in the brood nest in the absence of bees (Spiewok et al. 2007). We conclude that protection of the comb area via patrolling bees and thus the ratio of bee numbers to nest area are key factors for host colony resistance. Third line of defence: removal of eggs and larvae by host workers 


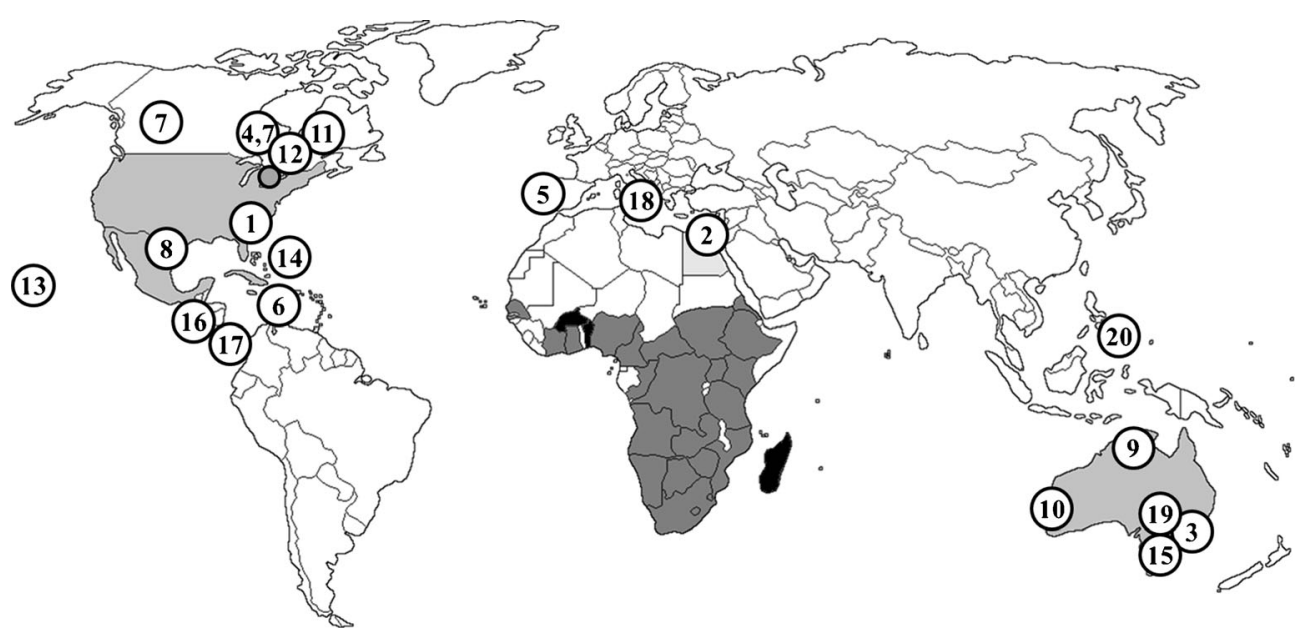

Figure 4. Global distribution and reported introductions of small hive beetles up to November 2015. Please refer to Neumann and Elzen (2004) and Neumann and Ellis (2008) for further references up to December 2008. Endemic distribution range in sub-Saharan Africa (dark grey areas), countries with well-established invasive populations (USA, Mexico, Cuba, Jamaica, Australia (medium grey areas), Canada (only Essex county, Ontario, Dubuc 2013; P. Giovenazzo, personal communication, dark grey circle) and not well established ones (Egypt, light grey area); new records in endemic range (black areas: Benin, Mensah et al. 2007; Burkina Faso, M'Peindagha Bongho 2009; Madagascar, Rasolofoarivao et al. 2013) and introductions (white circles) are shown: (1) 1996, Charleston, South Carolina, USA, (2) 2000, Itay-Al-Baroud, Egypt, (3) 2001, Richmond, NSW, Australia, (4) 2002, Manitoba, Canada, (5) 2004, Lisbon, Portugal, (6) 2005, Jamaica (FERA 2010), (7) 2006, Alberta and Manitoba, Canada, (8) 2007, Coahuila, Mexico, (9) 2007, Kununurra, North Australia (Annand 2008), (10) 2008, Perth, Australia (R. Spooner-Hart, N. Annand, personal communication), (11 ) 2008, 2009, Quebec, Canada (Dubuc 2013), (12) 2008, 2013 Ontario, Canada (Giovenazzo and Boucher 2010; Dubuc 2013), (13) 2010, Pana'ewa, Big Island, Hawaii (Robson 2012), (14 ) 2012, Cuba (Peña et al. 2014), (15) 2012, Naracoorte in Eastern South Australia (R. SpoonerHart, N. Annand, personal communication); (16) 2013, El Salvador (Arias 2014), (17) 2014, Nicaragua (Gutierrez 2014; Calderón Fallas et al. 2015), (18) Sovereto, Calabria, Italy (Mutinelli 2014; Mutinelli et al. 2014; Palmeri et al. 2015), (19) 2014, Renmark, Australia (R. Spooner-Hart, N. Annand, personal communication), (20) 2014, Lupon, Philippines (Brion 2015).

Given that adult SHBs were able to bypass patrolling workers and intrude the comb area, they may oviposit on the combs (Figure 3 and Table II). Honeybee workers can then remove eggs or hatched larvae (Table III), but SHBs may oviposit in gaps thereby protecting their offspring (Neumann and Härtel 2004). Given that the third line of colony defence fails, SHBs may start the so-called mass reproduction which can result in the full structural collapse of the entire nest (Hepburn and Radloff 1998; Neumann et al. 2010).

To prevent mass reproduction, adult bees can either prevent egg laying all together or detect and remove eggs once laid. One means to prevent egg laying is the social encapsulation of "corralled" SHBs (Neumann et al. 2001b), which may be due in part to more abundant propolis usage by African honeybees. Indeed, the numbers of confinements per colony and encapsulated beetles in these prisons were lower in European colonies (Ellis et al. 2003c) than in African ones (Neumann et al. 2001b). However, European honeybees guard beetle prisons significantly longer than Cape honeybees (Ellis et al. 2003d). African bees are more aggressive towards SHBs (Neumann and Elzen 2004). Therefore, African prison guards may be more efficient in preventing beetle escape.

Even if aggression by host workers is not very effective in killing beetles, it seems to 
contribute to colony resistance. Since African honeybees can show more aggression to adult SHBs than European ones (Neumann and Elzen 2004), A. tumida probably is under constant harassment in an African colony, which may minimize beetle reproduction. However, even though data suggest that European honeybees may treat $A$. tumida more defensively than they treat any other beetle species (Atkinson and Ellis 2011), the level of bee defensiveness can vary by colony (Atkinson and Ellis 2011). Indeed, another comparative study between European and African honeybees suggests that workers of European subspecies can be more aggressive toward the SHBs compared to African ones (Neumann et al. 2016b).

Colony mobility: absconding and migration African honeybee colonies respond to heavy SHB infestations by absconding (non-reproductive swarming; Hepburn and Radloff 1998). In general, African honeybee subspecies are more mobile compared to European ones (Hepburn and Radloff 1998) and absconding and subsequent colony mergers are common (Hepburn et al. 1999; Neumann et al. 2001c; Neumann and Hepburn 2011). However, it has also been shown that strong African colonies can tolerate large SHB infestations with only minor colony level effects (Ellis et al. 2003a). Similar to other bee diseases, there might be an upper limit of infestation that can be tolerated by the colonies (damage threshold), which can be exceeded in a few colonies due to SHB aggregations. Such a damage threshold appears to be different between African and European colonies.

Absconding is also induced in SHB-infested European honeybee colonies (Ellis et al. 2003a; Villa 2004). Because African subspecies are more prone to absconding than European subspecies (Hepburn and Radloff 1998), this may be yet another reason for better SHB resistance/less pest severity in African bees as they are more efficient in preparation for absconding (Spiewok et al. 2006a). Abandoned honeybee nests can serve as a breeding substrate for SHBs and subspecies differences in preparation for absconding appear to influence the reproductive success of SHB (Spiewok et al. 2006b). Absconding African colonies left significantly less brood and stores behind than European ones which would lead to less SHB reproduction (Spiewok et al. 2006b).

\subsubsection{Other social bees}

Bombus spp. Bumblebees do not occur in subSaharan Africa, but are native to the Americas, Europe and Asia (Michener 2000). Bumblebee colonies, Bombus impatiens, artificially infested with SHBs in the laboratory had fewer live bees, more dead adult bees and greater comb damage than controls (cf. Neumann and Elzen 2004). Moreover, a new SHB generation was produced in each unit (cf. Neumann and Elzen 2004). Adult beetles are also able to naturally infest commercial B. impatiens colonies in the field (Spiewok and Neumann 2006b) and in greenhouses (Hoffmann et al. 2008), probably because odour cues from bumblebee nests are attractive to adult SHBs (Spiewok and Neumann 2006b; Graham 2009; Graham et al. 2011a). After infestation, SHB females readily oviposit into $B$. impatiens nests, preferentially next to brood pots (Hoffmann et al. 2008). Contrary to earlier reports (cf. Neumann and Elzen 2004), B. impatiens workers were able to defend colonies against SHB by removing and attacking both adults and larvae. Such defence was not correlated with any $B$. impatiens colony phenotype (Hoffmann et al. 2008). Due to the similarities within the genus Bombus, it is most likely that nests of other bumblebees can also be infested. However, at present, field data are too scarce to draw definitive conclusions about the general role of bumblebees as alternative hosts.

Stingless bees Anecdotal reports of SHB invasions of both reasonably healthy and weakened stingless bee colonies, Tetragonula carbonaria, from Australia (Wade 2012; A. Dollin and R. Spooner-Hart, personal communication) prompted studies to elucidate the ability of stingless bees to defend themselves against this invasive species. Experiments with T. carbonaria 
colonies using diagnostic radioentomology showed that workers of this bee species mummify all invading adult SHB alive in $<10 \mathrm{~min}$ by coating them with a mixture of resin, wax and mud (Greco et al. 2010). The rapid live mummification strategy of $T$. carbonaria seems to effectively prevent beetle advancements and removes their ability to reproduce (Greco et al. 2010). The term mummification appears justified because honeybees do not coat live SHBs directly with propolis but instead confine them in prisons (Neumann et al. 2001b; Ellis et al. 2003c). Similar to T. carbonaria, non-invasive experiments with colonies of Austroplebeia australis (Halcroft et al. 2008) also showed that adult SHBs were entombed alive by workers within $6 \mathrm{~h}$ (Halcroft et al. 2011). Moreover, SHB eggs were efficiently destroyed, larvae and $59 \%$ of the adults ejected (Halcroft et al. 2011). It has also been stated that colonies of Dactylurina staudingeri are hosts of SHBs in West Africa (Mutsaers 2006). SHB infestations of wild and managed Melipona beecheii colonies have been reported from Cuba, where 7 out of 258 surveyed hives had SHB adults and two had both adults and larvae (Peña et al. 2014). SHB infestations were also associated with damage to recently founded M. beecheii colonies (Peña et al. 2014). Taken together, these observations show that SHBs can naturally infest stingless bee colonies in the field and further indicate that disturbed and/or newly founded colonies maybe at special risk. Undisturbed colonies of stingless bees seem to have evolved efficient defence mechanisms (Greco et al. 2010; Halcroft et al. 2011). In the stingless bee $T$. carbonaria, a control of SHBs after relocation of nests can be achieved via a screened mesh preventing beetle intrusion until the bees have rebuilt their defences (Wade 2012). Similar to bumblebees, more field data are urgently needed to conclude about the general role of stingless bees as alternative hosts of SHBs.

\subsubsection{Colony defence, stress and a "sit-and- wait" strategy of patient beetles?}

Low level SHB reproduction without obvious damage to the colonies (Spiewok and Neumann 2006a; Arbogast et al. 2012) often remains unnoticed by beekeepers and probably also by the bees. The important point is what is actually governing the switch from low level to overt SHB mass reproduction, because the latter can cause the full structural collapse of a strong honeybee colony within $<10$ days (Neumann et al. 2010). Contrary to common belief, SHBs do not always reproduce in colonies with adult beetles present. Indeed, field surveys often reveal only SHB adults, but no eggs and larvae in infested colonies (Spiewok et al. 2008; Lawal and Banjo 2007, 2008; Neumann and Hoffmann 2008; Mutinelli et al. 2014). Since female SHBs obviously cannot produce an indefinite number of eggs, it appears adaptive to limit reproduction to time windows/ opportunities, when their offspring actually have the best chance to escape removal and/or attack. These time windows provide an opportunity to lay eggs when overall conditions are suitable. Such SHB reproductive options might be linked to overall colony well-being and management. Indeed, even in Africa, successful SHB reproduction appears most successful in weak and stressed honeybee colonies and is far less common in strong ones (Lundie 1940; Schmolke 1974; Hepburn and Radloff 1998). Queen loss as one potential stressor had no significant impact on removal of SHB eggs and larvae in African honeybee colonies A. m. capensis (Spiewok and Neumann 2006c). Similarly, it has been reported that queenless colonies of European subspecies in Australia were no more attractive or susceptible to SHBs, when bee populations were high (Annand 2011a, b). However, an Australian beekeeper reported losing $400(20 \%)$ hives due to SHB after re-queening his hives in the summer 2006/2007 (Annand 2011b). Nevertheless, healthy, strong hives attracted more SHBs than weak hives, but when hive populations decreased to very low numbers, probably as a direct result of being queenless, these hives became far more susceptible to SHB damage (Annand 2011a). These observations are in line with Mustafa et al. (2014), also reporting a higher susceptibility of smaller European-derived honeybee colonies. African honeybee colonies undergoing preparation for absconding did not completely remove SHB offspring (Spiewok et al. 2006b), also supporting the 
idea of a susceptibility time window during colony life.

Other colony stressors could impact SHB oviposition and/or reproductive success, e.g. beekeeping management of colonies. The transportation of bee colonies would likely disrupt the balance of SHB and worker bee policing, potentially allowing egg laying and larval growth, but migratory beekeepers in the USA have not reported SHB damage following colony movement. This lack of obvious damage after transportation might be explained by observations that adult SHB tend to leave colonies when transported (N. Annand, personal communication). However, it is known from field experience that the manipulation of combs during hive inspections can result in larval damage in the following days (J. Pettis and P. Neumann, personal observations), e.g. SHB reproduction has been observed when combs are pushed too close together (J. Pettis, unpublished data). Adult SHBs are probably able to detect such areas, because they can escape pursuit by the workers. There, SHB reproduction can happen without inference by host workers. This is, however, strictly limited to managed colonies and beekeepers quickly learn to correctly space brood combs in their boxes. Meikle et al. (2015) artificially infested honeybee colonies with SHB eggs or adults and tried to weaken colonies/induce "stress" by removing brood frames. However, despite those efforts, no larvae were observed exiting from, or during the inspection of, any hives (Meikle et al. 2015), thereby suggesting that the triggers of destructive SHB mass reproduction can be more complex.

In conclusion, it appears as if a colony size, in particular the ratio of workers to nest area (Lundie 1952), e.g. decreased due to queenloss (Annand 2011a), or other pathogens can play a role in SHB mass reproduction. For example, interactions between SHBs and the ubiquitous mite Varroa destructor have been suggested to play a role (Connor 2011a; Martin 2013). However, two systematic studies found no significant evidence (Delaplane et al. 2010; Schäfer et al. 2010c), suggesting that such combined effects of $A$. tumida and $V$. destructor are rather weak. In Victoria, Australia, SHBs can be found in healthy strong European-derived honeybee colonies, but seemingly without having any impact (N. Annand and R. Spooner-Hart, personal communication). However, SHBs may seriously impact Australian honeybee colonies that are "compromised"/diseased/drone layers or subject to poor beekeeping management practices (Annand 2011b). This again supports the idea that colony management by humans can be a trigger for SHB reproductive success.

Since SHBs are trophallactically well fed in honeybee colonies (Ellis et al. 2002d; Ellis 2005 c), they can stay within sheltered host nests for long time (" 6 months and probably even longer" Lundie 1940). It therefore appears as if SHBs use a "sit-and-wait" strategy. At least, adult SHB females live apparently long enough (up to 16 months, Somerville 2003) to be physically able to wait for any event/development compromising colony defence. The female biased sex ratio of adult SHBs in African, Australian and US field populations (Schmolke 1974; Ellis et al. 2002b; Spiewok and Neumann 2012) points in that direction. The compromise of colony defence is analogous to down-regulation of immune functions in individual insects (Schmid-Hempel 2005) and might be triggered by a whole range of factors such as queenstate, infections with other pathogens, season (colony migration, Hepburn and Radloff 1998), colony management or any factors resulting in disturbance-induced absconding (Spiewok et al. 2006a). Then, given sufficient protein-rich food remaining, to ensure ovary activation and reproduction, SHBs are able to adequately exploit that time window, even if limited, with a less defended (or not in case of absconding) rewarding food source by quickly laying a high number of eggs per day. The capability of SHB mass reproduction is well documented, e.g. 80 parental SHB adults produced $>36,000$ adult offspring in 63 days (Mürrle and Neumann 2004). The long adult longevity of SHBs seems to constitute a $k$-component of an overall $r$-strategy (Ibler 2013), associated with short-term windows of reproductive bursts either in colonies or other temporarily available food stuff, except low-level reproduction (Spiewok and Neumann 2006a).

However, as in most other cases of our knowledge of SHB biology and control, more data are required to pinpoint the actual reasons for the 
breakdown of colony defence fostering the highly destructive mass reproduction of SHB. In particular, long-term studies will be required to be able to monitor natural time windows (e.g. colony migration) or more experimental disturbances.

\subsubsection{Beetles in colonies, other than A. tumida}

A number of other beetle species can be associated to a varying degree with social bee colonies (Hepburn and Radloff 1998; Ellis et al. 2008; Atkinson and Ellis 2011; Krishnan et al. 2015) and may range from harmless associates (e.g. Cychramus luteus, Coleoptera: Nitidulidae, Neumann and Ritter 2004) to damaging parasites (e.g. Oplostomus /Hoplostoma fuligineus in A. mellifera, Hepburn and Radloff 1998). While some beetle species only seek shelter and/or food in social bee colonies (e.g. C. luteus in A. mellifera, Neumann and Ritter 2004), others also reproduce in the host colonies (e.g. Cryptophagus hexagonalis in A. mellifera, Haddad et al. 2008). Large hive beetles (Oplostomus/H. fuligineus, Coleoptera: Scarabaeidae) are not reproducing in colonies (Donaldson 1989; Torto et al. 2010b), but adults of this beetle feed on bee brood, pollen and honey (Hepburn and Radloff 1998) and can cause significant damage and induce absconding in Apis mellifera scutellata (P. Neumann, personal observations). The larvae of this species reproduce in cattle dung outside of colonies (Donaldson 1989). In contrast, SHB adults are comparatively harmless to colonies (Neumann and Elzen 2004). It is the larval stage of this species, which can cause considerable damage. A few Brachypeplus spp. in Australia have larvae and adults that feed on the wax and honey in colonies of stingless bees Tetragonula spp. (Lundie 1940; Habeck 2002). Brachypeplus sp. adults can also occasionally be found in honeybee colonies, and even larvae have been found in a hive (Gillespie et al. 2003).

None of these beetle species have been reported to pupate in host colonies. The Nitidulid Haptoncus luteolus therefore represents a novel degree of beetle association with social bee colonies (see Ellis et al. 2008), because it apparently can pupate within colonies after feeding on pollen, thereby separating this species from the previously reported cases (Krishnan et al. 2015). Preliminary observations suggest that heavy infestations with $H$. luteolus may cause colony collapse in the stingless bee Tetragonula laeviceps (Krishnan et al. 2015). Comparative studies with those other beetles (e.g. Atkinson and Ellis 2011) may also enable to better understand the biological mechanisms driving the interactions between $A$. tumida and host bees.

\subsection{Outside of colonies}

\subsubsection{Apicultural facilities}

SHBs may use a variety of protein sources in beekeeping storage facilities and or honey extraction facilities (Hood 2011). Combs containing stored pollen and or dead bee brood in stored combs can be utilized by SHBs to reproduce. Honey removed from colonies is particularly vulnerable to SHB reproduction if the combs contain pollen or brood. Additionally, even if the honey is extracted, the supers containing the remaining honey (wet supers) can allow for SHBs to reproduce if small amounts of pollen and or brood are present. Potentially, the yeast Kodamaea ohmeri may provide some protein to supplement the SHB larval diet (see below). Lastly, any combs, wax or debris that is present in the beekeeping facility could serve as a source for SHB reproduction. General sanitation in beekeeping facilities is a major means to limit SHB reproduction and population build-up (see below).

\subsubsection{Alternative food sources}

SHBs may use fruits as alternative food sources both in the presence and absence of honeybee colonies in the field (cf. Neumann and Elzen 2004; Buchholz et al. 2008). Moreover, a complete life cycle can be achieved in the laboratory on fruits (Kei apples (Ellis et al. 2002c); banana, cantaloupe, pineapple and mango (Keller 2002); mango, banana and grapes (Buchholz et al. 2008); green grapes, oranges, inoculated oranges and cantaloupe (Arbogast et al. 2009b, 2010); and on decaying meat (beef schnitzel, Buchholz et al. 2008). SHBs were also able to successfully 
reproduce on an artificial "manduca" diet (Keller 2002). However, the number of offspring per breeding couple is lower than on bee products such as pollen (Ellis et al. 2002c; Keller 2002; Buchholz et al. 2008). Adult SHBs were rarely observed on fruit buckets in the field, reproduced only when caged and in much smaller numbers than Drosophilidae and other Nitidulidae (Buchholz et al. 2008). Moreover, less than $2 \%$ of adult SHB survived on blooming pot plants and no reproduction was recorded, suggesting that flowers are unlikely to serve as an alternative food and breeding substrate (Buchholz et al. 2008). This contrasts $A$. tumida to $A$. concolor, which is a regular flower visitor in NSW, Australia (Buchholz et al. 2008). There are no reports so far that the SHB is a pest of stored products (e.g. cheese or meat), suggesting that this is a rare event or even absent. Nevertheless, reproduction on alternative diets, which may even include fungi or other food resources (Arbogast et al. 2010), appears to be sufficient for SHB population growth (Arbogast et al. 2009b). Given that SHBs are able to exploit such alternative resources regularly, this affects active dispersal and range expansion, because reproduction in the absence of bees would facilitate long-range dispersal by flight through successive generations (Arbogast et al. 2009b). Although successful SHB reproduction is in principal possible on a large variety of different diets, they should prefer social bee colonies whenever possible to maximize their reproductive output. However, our knowledge of the actual amount of SHB reproduction on alternative food sources outside of colonies is still limited. The presence of $A$. tumida larvae in fruit, fungi or other alternative foods collected in natural settings lacking bees would provide positive proof (Arbogast et al. 2010). One approach might be to collect SHB adults in woodlands and to test their gut contents for evidence of feeding on materials other than bee products (Arbogast et al. 2010).

In conclusion, the current data clearly show that SHBs are in principle able to exploit a variety of alternative food resources, but there is very little evidence that they actually do so in the field. Nevertheless, at the current stage of knowledge, we cannot exclude that the presence of an abundant food source other than social bee colonies may serve as a refuge for the SHBs and as a source of further infestations.

\subsection{Pupation in the soil}

Wandering larvae can migrate long distance to reach the soil (>200 m, Sanford 1998). Pettis and Shimanuki (2000) showed that when soil surrounding hives in Florida was sandy and loose in consistency, most wandering larvae were found within $1 \mathrm{~m}$ of the hive and at a depth of no more than $10-20 \mathrm{~cm}$. Laboratory data on more dense clay soils indicate that wandering larvae would most likely try and reach less compact soil in order to facilitate burrowing and pupation and increase pupation success (Ellis et al. 2004d; Meikle and Diaz 2012). SHB populations successfully developed in various types of soil, and vertical movement of larvae in the soil was not influenced by soil type (de Guzman et al. 2009).

In soil, the duration of SHB pupation can range between 2 weeks and 2 months (Lundie 1940; Schmolke 1974; Neumann et al. 2001a; Mürrle and Neumann 2004; Haque and Levot 2005; Meikle and Patt 2011; Meikle and Diaz 2012; Bernier et al. 2014) and abiotic factors are known to play a key role. Indeed, it is well known that both duration and success of SHB pupation are governed by temperature, soil texture and humidity (Lundie 1940; Schmolke 1974; Neumann et al. 2001a; Ellis et al. 2004d; Mürrle and Neumann 2004; Haque and Levot 2005; de Guzman and Frake 2007; de Guzman et al. 2009; Meikle and Patt 2011; Meikle and Diaz 2012; Bernier et al 2014). Sandy, moist soil and warm temperature $\left(24.6 \pm 1.3^{\circ} \mathrm{C}\right)$ seem to provide good conditions with only 23 days needed to complete pupation and only $8.5 \%$ mortality (Ellis et al. 2004d). There may be as many as six generations per year under moderate US and South African climatic conditions (cf. Neumann and Elzen 2004), but this could potentially be even higher under tropical conditions. Indeed, de Guzman and Frake (2007) showed that almost 16 complete life cycles could be achieved in a year, with constant $34{ }^{\circ} \mathrm{C}$.

An entire life cycle of a SHB can be achieved in a single Eppendorf tube (Neumann et al. 2013). Therefore, intraspecific competition for space is rather unlikely in the soil, unless severe space 
limitations may interfere with the construction of SHB pupation chambers (e.g. in laboratory rearing, Mürrle and Neumann 2004). However, subterranean mating of SHB adults is most likely because they reach sexual maturity after 7 days (cf. Neumann and Elzen 2004) and often remain jointly underneath the soil surface without emerging for up to 35 days (Mürrle and Neumann 2004). What factors trigger adult SHB emergence from the soil is currently unknown, but light rain maybe involved (simulated with water and a manual pump sprayer in the laboratory, P. Neumann, unpublished data). The impact of salinity and $\mathrm{pH}$ value on SHB pupation are currently unknown.

\subsection{Natural enemies}

The ability of entomopathogenic fungi to kill SHBs was already reported by Lundie (1940). Since, various fungi were isolated from and/or have proven effective against SHBs (Table III; Richards et al. 2005; Cabanillas and Elzen 2006; Muerrle et al. 2006; Ellis et al. 2010). Recently, isolates of both Metarhizium and Beauveria showed good efficacy against SHBs in laboratory and field assays (Leemon and McMahon 2009; Leemon 2012), where the Metarhizium isolates showed best results against larvae (three isolates were able to kill more than $70 \%$ of larvae in 1 week), while the Beauveria isolates performed best against adult beetles (99-100\% adult SHB mortality in 2 weeks). Susceptibility of SHBs was also shown to entomopathogenic nematodes where several Heterorhabditis and Steinernema strains have provided adequate SHB control with 88-100 \% mortality (Table III; de Guzman et al. 2009; Cabanillas and Elzen 2006; Ellis et al. 2010; Shapiro-Ilan et al. 2010; Cuthbertson et al. 2012). Three different Bacillus thuringiensis Berliner strains (B. thuringiensis var. aizawai, $B$. thuringiensis var. kurstaki and B. thuringiensis var. San Diego tenebrionis) showed no effect on reproductive success of SHBs (Buchholz et al. 2006). Ants are generally considered a potential biological control agent, and the ant Pheidole megacephala was identified as a key predator of larvae in Kenya (Torto et al. 2010a). Furthermore, a protozoan pathogen was discovered in the Malpighian tubules of adult
SHBs (Wright and Steinkraus 2013), and Strauss et al. (2010) reported the storage mite Caloglyphus hughesi on laboratory-reared SHBs in South Africa.

The impact of pathogens and predators may be less severe in the rather protected environment of social bee colonies due to host defence and sanitation (e.g. propolis, Evans and Spivak 2010) compared to food sources outside of colonies, but there are no comparative data in this regard. Likewise, the impact of natural enemies has never been compared between endemic and invasive populations. Therefore, release from natural enemies cannot be excluded as one key factor driving SHB invasion success.

\subsection{Competitors}

Since SHBs are the only known species to be able to induce trophallactic feeding in honeybees (Ellis et al. 2002d), there is most likely no competitor with adult SHBs in colonies. In sharp contrast to A. tumida, the bee louse, Braula coeca, is not able to induce trophallaxis in honeybees. Instead, the bee louse takes advantage of two bees feeding each other (Morse and Nowogrodzki 1990). Sitting on the head or abdomen of a worker or the queen, the louse quickly moves forward and steals food during the food exchange between the two bees (Morse and Nowogrodzki 1990). When colonies are less well defended or honeybees abscond, SHBs can take advantage of the then unprotected food (brood, honey and pollen, see above). Such food will also be consumed by other species such as ants, which can therefore be both natural enemies (Arbogast et al. 2010) as well as competitors for reproduction (Spiewok et al. 2006b). Likewise, wax moths and SHBs can compete for the same resource and may negatively influence the reproductive success of each other (Spiewok et al. 2006b). On fruits and other food resources outside of colonies, Drosophilidae and other Nitidulidae would compete with SHBs (Buchholz et al. 2008).

In conclusion, our knowledge of natural enemies and competitors is still fairly limited, e.g. the role of tropical subterranean army ants for SHB pupation success (Kronauer 2009) and of 
nocturnal predators (Williams-Guillén et al. 2008) of flying adult SHBs is unknown.

\subsection{Small hive beetles as vectors}

A. tumida has been shown to act as a vector for Paenibacillus larvae, the causative agent of American foulbrood (AFB; de Graaf et al. 2013), with both adults and larvae becoming infected with spores when exposed to honeybee brood combs with clinical symptoms (Schäfer et al. 2010b). The subsequent field test, where honeybee colonies were infested with contaminated adult beetles, resulted in higher numbers of $P$. larvae spores in adult workers and honey (Schäfer et al. 2010b). Adult SHBs have also shown the potential to act as vectors for honeybee viruses (Eyer et al. 2009a, b). It has been demonstrated that adult SHBs can be infected with deformed wing virus (Eyer et al. 2009a) and sacbrood virus (Eyer et al. 2009b) via foodborne transmission.

\subsection{Beneficial yeast associated with small hive beetles}

During larval reproduction, combs become covered in a slimy material that is part honey and part larval in origin (Lundie 1940). From this "slime" and adult beetles, researchers isolated a yeast that appears to function as an attractant to SHB adults (Benda et al. 2008). The yeast, $K$. ohmeri, produces substances that are similar to bee pheromones, and a dough containing the yeast has been tried in traps to increase attractiveness to adult beetles (Arbogast et al. 2007; Torto et al. 2007a; Hayes et al. 2015). K. ohmeri has also been found in both managed and wild colonies of bumblebees (Graham et al 2011b). Organic acids used for mite control were shown to inhibit the growth of $K$ ohmeri (Schäfer et al. 2009). While initially very promising as an attractant (Torto et al. 2005), additional research is needed to fully realize the potential of this yeast in the management of SHBs.

Besides control, it appears as if there is more of a relationship between $K$. ohmeri and the SHB than just the release of volatiles that are attractive to SHBs (Torto et al. 2007c). It may well be that there is a symbiotic relationship between the two. So contaminating the honey with $K$. ohmeri allows the yeast to grow by fermenting honey and may thereby provide some protein to supplement the SHB larval diet when feeding predominantly on honey. Moreover, there might be a human health risk with this yeast as well (Santino et al. 2013).

\subsection{Small hive beetle aggregation pheromone?}

Analogous to bark beetles (Byers 1989), pheromone-mediated aggregations of adult SHBs might be adaptive to overcome host defence (Neumann and Elzen 2004). Mustafa et al. (2006) showed SHB aggregation in laboratory plastic cages, and field studies have shown that SHB distribution among honeybee colonies at an apiary is different from a random distribution (Neumann and Elzen 2004; Spiewok et al. 2007). In a single A. $m$. scutellata colony, 491 adult SHBs were found, while all other colonies at the same apiary showed low infestation levels (Neumann and Elzen 2004). The maximum numbers of adult SHBs in European honeybee colonies so far recorded in functional colonies in the invasive ranges were 1071 in Umatilla, Florida (USA) and 2029 (P. Neumann, unpublished data) and 3027 (N. Annand, unpublished data) in Richmond, NSW, Australia. However, colony phenotypes (number of bees, amount of brood or stores) do not significantly influence infestation levels with adult SHBs (Spiewok et al. 2007), thereby indicating that cues other than host colony size and food stores are responsible for their attractiveness. Aggregation pheromones have been described for a variety of Nitidulidae species and are widely used as control agents (Petroski et al. 1994; James et al. 2000). We consider it very likely that a similar pheromone plays a role for long-range host finding and aggregations of SHBs. Observations that males tend to infest before females (Neumann and Elzen 2004) indicate that the aggregation pheromone might be male produced as in Carpophilus obsoletus and is attractive to both sexes (Petroski et al. 1994), but no sex-specific differences in SHB brain structure were found (Kollmann et al. 2015). Moreover, the sex ratios did not significantly differ between 
recently infested apiaries and longer infested ones in another study (Spiewok and Neumann 2012). Synergistic effects between food odours and aggregation pheromones for attracting SHB might also play a role as shown for Carpophilus lugubris (Lin et al. 1992). More research is needed to identify and evaluate the potential impact of different compounds such as aggregation pheromones, food volatiles or any synergism between pheromone and food volatiles on the short- and long-range dispersal and host finding of SHBs.

\subsection{Seasonality in small hive beetle reproduction}

Most beetles captured in baited traps near $\mathrm{La}$ Crosse, FL, USA were captured during the spring and summer months, with peak captures during May and June (Arbogast et al. 2010). In St. Gabriel, Louisiana, USA, SHB populations varied throughout the year, with peak infestations observed in September and November (de Guzman et al. 2010). Similarly, SHB populations in Georgia seem also to rise by July/August and reach their peak by September/October (Berry 2009). In Louisiana, SHB abundance was significantly correlated with the proportion of hot days, but not with the proportions of cool, dry or humid days or the percentage of days with rainfall (de Guzman et al. 2010). On the other hand, trap captures in Kenya indicated that SHB was present in honeybee colonies in low numbers all year round, but it was most abundant during the rainy season and with over $80 \%$ trapped during this period (Torto et al. 2010a). Likewise, traps installed in Kenya in front of infested hives over an entire year showed that more wandering larvae were leaving infested colonies associated with the "kusi monsoon" (Arbogast et al. 2012). In contrast, in Nigeria, both adult and larval SHBs were more often found inside colonies $(N=437)$ during the dry season (28,057 adults, 5210 larvae) compared to the wet season (7869 adults, 831 larvae; Lawal and Banjo 2008).

In South Africa, mated adult SHB females provided in the laboratory with adequate food did not readily oviposit in July/August unless incubated at $30{ }^{\circ} \mathrm{C}$ for a week (P. Neumann, unpublished data). Similarly, Australian beekeepers reported almost no damage by SHB larvae in June/July/August (Rhodes and McCorkell 2007). In Australia, SHB populations in hives followed a cyclical pattern, which peaked in late autumn then declined through winter to a minimum in late spring (Annand 2011b). Most SHB movements in NSW, Australia occurred in April and May; however, a major spike was also observed in October (Annand 2011b). Differences between years have also been reported, e.g. SHB numbers in Gauteng, South Africa were considerably higher in winter 2011 compared to winter 2010 (Strauss et al. 2013).

In conclusion, several observations suggest considerable seasonal variation in SHB reproduction. Therefore, it appears as if season might also play an important role, e.g. by triggering host colony migration (Hepburn and Radloff 1998), fostering SHB reproduction (e.g. pupation) and inducing high SHB mortality over winter (Schäfer et al. 2011), with subsequent consequences of higher/lower infestation levels (Spiewok et al. 2007).

\subsection{Dispersal}

\subsubsection{Natural range expansion}

Adult SHBs are strong fliers and are capable of flying several kilometres $(>10 \mathrm{~km}$ being possible, cf. Neumann and Elzen 2004). However, not a single study has systematically addressed this matter and how far a SHB could actually fly within a given time period is unknown. Apiary density, SHB population levels and ongoing mass reproduction seem to govern infestations of newly installed apiaries (Spiewok et al. 2008). In Australia, those apiaries located in forested habitats showed higher infestation levels, possibly due to the presence of feral colonies (Spiewok et al. 2008), but in Uganda, A. tumida appeared to favour hives in the open (Kugonza et al. 2009). After emergence from the soil, adult SHBs seem to prefer long-range flights, because they tend to ignore neighbouring host colonies of both A. mellifera and B. impatiens (Neumann et al. 2012). It has been reported from the USA that SHB males tend to fly earlier than females (Neumann and Elzen 2004), but this was not 
found in Australia and Africa (Spiewok and Neumann 2012). The sex ratio was biased towards females confirming earlier reports (Schmolke 1974; Ellis et al. 2002a), but did not significantly differ between recently infested apiaries and longer infested ones (Spiewok and Neumann 2012). Adult SHB can potentially disperse between managed honeybee colonies within an apiary and between apiaries (Spiewok et al. 2007, 2008), apicultural facilities (e.g. honey houses, Spiewok et al. 2008), feral honeybee nests (Neumann et al. 2012), nests of other social bees (Bombus spp.: Spiewok and Neumann 2006b; Hoffmann et al. 2008; stingless bees: Mutsaers 2006; cf. Greco et al. 2010; cf. Halcroft et al. 2011; Peña et al. 2014; etc.) as well as fruits (Buchholz et al. 2008) and even potentially other food stuff outside of colonies (Buchholz et al. 2008). There is an urgent need to use the existing marking methods for adults (de Guzman et al. 2012; Neumann et al. 2013) to trace back the actual dispersal pathways of adult SHB.

\subsubsection{The small hive beetle Hitchhiker's guide: human-assisted dispersal}

The rapid range expansion of SHBs is likely to result from migratory beekeeping and movement of package bees and beekeeping equipment (Neumann and Elzen 2004; Gordon et al. 2014; Annand 2011b). In the USA, the more southern states (North Carolina, Georgia, South Carolina and Florida) became infested between 1996 and 1998 and then the states bordering Canada only 2 years later in 2000 (Neumann and Elzen 2004). This large jump in dispersal is most parsimoniously explained by migratory beekeeping, since managed colonies over winter in Florida before they are transported north for pollination in the spring (Pettis et al. 2014).

\subsection{What is the small hive beetle?}

Within the literature, several different definitions have been put forward ranging from scavengers (Hepburn and Radloff 1998) over parasites (Neumann and Elzen 2004) to symbionts (Ellis and Hepburn 2006). Data have emerged that SHB actually fit several ecological definitions. They can feed on dead animals (scavenger; honeybees; conspecifics $=$ cannibalism (Neumann et al. 2001b); beef schnitzel (Buchholz et al. 2008)) and live animals (predator; Pirk and Neumann 2013) as well as on fruits (phytophagous (Keller 2002; Ellis et al. 2002c; Buchholz et al. 2008; Arbogast et al. 2009a, 2009b, 2010). Moreover, they are able to steal food from their hosts via trophallactic mimicry (kleptoparasite; Ellis et al. 2002d; Ellis 2005c; Neumann et al. 2015). In conclusion, the authors agree with the line of thoughts initially developed by Arbogast et al. (2009b): A tumida can be considered as an ecological generalist.

\section{GLOBAL DISTRIBUTION AND PEST STATUS}

\subsection{Endemic range in sub-Saharan Africa, including Madagascar}

The two new SHB records from West Africa (Benin and Burkina Faso, Figure 3) are well in line with previous records from sub-Saharan Africa (El-Niweiri et al. 2008; Neumann and Ellis 2008). In Madagascar (Figure 3), A. tumida appears to be widespread and well established since it was found in all honeybee colonies of three districts from the "Highlands" and on the eastern coast (Rasolofoarivao et al. 2013). Since there are no reports of any introductions or of any serious damage to local colonies, it seems as if the SHB is endemic to Madagascar.

In its native range, the SHB is usually only a minor pest (Pirk and Yusuf 2015), because successful reproduction appears most often in weak, stressed honeybee colonies or in recently abandoned ones and is far less common in strong colonies (Lundie 1940; Schmolke 1974; Hepburn and Radloff 1998; Neumann and Elzen 2004). Strong African honeybee colonies can usually prevent or postpone successful beetle reproduction (Neumann and Elzen 2004). In such colonies, SHBs usually have to wait until absconding (non-reproductive swarming) for various reasons, possibly including heavy SHB infestations (Hepburn and Radloff 1998; Neumann and Elzen 2004). However, there might be regional differences within its endemic range. Indeed, 
while SHBs appear to be rare in Kenya (Torto et al. 2010a) and in Uganda (Kugonza et al. 2009), it seems to be the most common honeybee pest in Nigeria (40.5\% of hives infested with adults, $9.6 \%$ with larvae; Lawal and Banjo 2007), where a total of 28,057 adult SHB were sampled from 437 colonies (Lawal and Banjo 2008). Accordingly, the SHB seems to be a bigger problem for beekeepers in West Africa compared to East Africa or the Horn of Africa (Mutsaers 2006; Akinwande et al. 2013). During South African winter, SHB pupation success is rather unlikely, at least in the Eastern and Western Cape provinces and in the Highveld.

\subsection{Invasive populations}

\subsubsection{The Americas}

So it begins: USA In November 1996, the first unidentified SHB specimens were collected in Charleston, South Carolina (Hood 2000). Two years later, SHBs were well established and caused considerable damage to apiculture in Florida ( $\sim$ 3 million only in 1998, Ellis et al. 2002c). It was thus far too late for any eradication measure, when the beetles were confirmed to be A. tumida in St. Lucie, Florida (June 1998, Hood 2000). Since then, the SHB has well established across the continental USA with all 48 contiguous states having had some positive finds (J. Pettis, personal observations). Even strong colonies of local European-derived honeybee subspecies can be taken over and killed by SHBs in the USA (Neumann and Elzen 2004). A survey on managed colony losses in the winter of 2006-2007 revealed that commercial beekeepers believed invertebrate pests ( $V$. destructor, Acarapis woodi and/or SHBs) were the leading cause of colony mortality (Van Engelsdorp et al. 2007). Besides that, SHBs can interfere with honey harvest and storage (Spiewok et al. 2007; Hood 2011).

In April 2010, a beekeeper in Pana'ewa, on the Big Island of Hawaii, found adult specimens, which were confirmed to be SHBs (Robson 2012). Since then, the SHB has well established and has spread from the Big Island to Oahu (2010), Molokai (2011) and Kauai (2012) (Martin 2013). It had devastating effects on the local honeybee industry with European-derived colonies (Connor 2011a). In a survey, $55 \%$ of managed colonies were reported to be lost; $80 \%$ of such losses were attributed by the beekeepers to SHBs or a combination of $V$. destructor and SHBs (Connor 2011a). The abundant and unmanaged feral European-derived honeybee colonies (thanks to the absence of $V$. destructor prior to 2010) may have been a considerable source of the massive numbers of beetles (Connor 2011a) similar to Australia (Neumann et al. 2012). Finally, the environmental conditions on Hawaii are perfectly suited for SHB pupation (Connor 2011b). The establishment of SHBs has resulted in lost export markets to the local major queen bee industry due to quarantine restrictions in some countries (Robson 2012).

Besides Hawaii, the states most severely affected by the SHB have been Florida and the southeastern USA (cf. Neumann and Elzen 2004) and queen breeders in various states (J. Pettis, personal observations). So far, there are no confirmed reports of SHBs in Alaska and Puerto Rico.

Up to the northern limits: Canada There have been SHB outbreaks in Canada in 2002 (Manitoba), 2006 (Alberta and Manitoba), 2008 (Quebec and Ontario), 2009 (Quebec), and 2013 (Ontario) (Clay 2006; Neumann and Ellis 2008; Giovenazzo and Boucher 2010; Kozak 2010; Dubuc 2013). Ontario has had an established SHB population in the Essex county since 2010 (P. Giovenazzo, personal communication). This is the most southern point of Ontario, and the local strategy has been to declare this region SHB positive and enforce no movement of colonies or apicultural material out of this region. When SHB is found elsewhere in the province, the infested colonies are either exterminated or colonies transported inside the quarantine area of the SHB positive Essex region (Dubuc 2013; P. Giovenazzo, personal communication). Movement of bees from Ontario to Quebec (and all other Canadian provinces) is under strict veterinary surveillance. Still ongoing surveys along the Quebec-US border over the past 6 years have not detected SHB since 2012 (Giovenazzo and Bernier 2015; P. Giovenazzo, personal communication), with the exception of a single 
case in Ormstown, Quebec, in 2013 (Dubuc 2013). Interestingly, SHBs appear to be absent in southern British Columbia, the most western Canadian province with an almost Mediterranean climate, although SHB is well established in the US state of California.

In conclusion, SHB is not well established in Canada (except Ontario), probably thanks to unfavourable climatic conditions, and can be easily managed, but the commercial impact (trade regulations, movement restrictions, etc.) can nevertheless be serious for local beekeepers and their industry.

On the front line: Central America and the Caribbean Since its first report in 2007 (Del Valle Molina 2007), the SHB is now well established in at least eight states of Mexico. Especially in the tropical states (e.g. Yucatan), infestation levels can be extremely high with hundreds or even thousands of adult SHBs in a single infested hive (Loza et al. 2014). This is most surprising since the local honeybees are Africanized and thought to be less susceptible to SHB infestations. Either local Africanized bees support more SHB reproduction than African ones and/or reproduction in local hosts other than honeybees is crucial (e.g. in colonies of stingless bees). Alternatively, but not mutually exclusive, enemy release (Torchin et al. 2003) might enhance pupation success compared to the endemic range of SHBs in Africa. More detailed data from Mexico are urgently required to clarify this question, which would also be relevant for the tropical parts of Central and South America and possibly even Southeast Asia.

In 2013, SHBs have also been detected in El Salvador (Arias 2014). A follow-up survey in December 2014 detected SHBs in only 68 out of 1700 hives suggesting a rather localized outbreak (V. Landaverde, personal communication). From Nicaragua, SHBs were reported in February 2014 in Rivas, which is bordering Costa Rica (Gutierrez 2014; Calderón Fallas et al. 2015). However, it is currently unknown, whether it is established in this country or localized. In Costa Rica, two SHB surveys in 2012 and 2014 yielded negative evidence and since then no SHB outbreaks have been reported (Ramírez et al. 2014; R. A.
Caldéron, personal communication). Given that SHBs are now well established in the Yucatan region of Mexico bordering Belize and Guatemala on the north (Loza et al. 2014), it is just a question of time until the SHB invasion front will reach Belize and Guatemala.

The SHB was introduced into Jamaica in 2005 (FERA 2010) and has spread across the entire island since (H. Smith, personal communication). Although earlier reports state that it can be a very serious pest of local European honeybees (FERA 2010), the well-established SHB populations are seemingly not causing problems for apiculture $(\mathrm{H}$. Smith, personal communication). This is most astonishing since local beekeepers apparently rely only on the natural ability of the honeybees to keep the SHB population under control and do not use any measures, except placing apiaries on concrete surfaces (H. Smith, personal communication). Maybe the local bees are Africanized, but still retain some desired European traits (e.g. gentleness, Rivera-Marchand et al. 2012). Then, it would not be surprising that they can better cope with SHB infestations.

In Cuba, the SHB has been confirmed in 2012 (Milián 2012; Darias 2014). A. tumida is currently present in the provinces of Villa Clara, Cienfuegos, Matanzas, La Havana, Mayabeque, Artemisa and Pinar del Rio and expected to extend to the whole country (Darias 2014). So far, no major effects on local honeybees have been reported (Borroto et al. 2014), which might be due to low initial infestation rates (Spiewok et al. 2007). Indeed, it took 2 years in the USA for SHB population build-up before significant damage to apiculture occurred (Sanford 1998). There are no further published reports of SHB from the Caribbean.

\subsubsection{Egypt}

In summer 2000, SHB was detected in Itay-AlBaroud and subsequently in other apiaries along the Nile Delta (cf. Neumann and Elzen 2004). However, a latter extensive survey could not confirm it (Hassan and Neumann 2008), and no SHB damage to local apiculture has been reported since (Y. Ibrahim, personal communication). It seems as 
if the SHB is not well established in Egypt, but the underlying reasons remain unknown.

\subsubsection{Australia}

In July 2002, SHB damage was noticed in Richmond, New South Wales, Australia. The beetles were only identified as $A$. tumida in October 2002 (Minister for Agriculture 2002). The Australian government decided against an eradication program, because SHB reproduction was already found in feral honeybee colonies (Gillespie et al. 2003). Since then, nomadic beekeeping and transport of beekeeping equipment/ bee food appeared to play a key role for SHB spread (Annand 2008, 2011a, b; Gordon et al. 2014; Spooner-Hart et al. 2016). Indeed, several long-range introductions into previously SHBfree areas have been reported (e.g. 2007, Kununurra; 2007, Perth; 2012, Naracoorte; 2014, see Figure 3). In Kununurra, it appears as if SHB has become established (Annand 2008). Hives infested with SHB were transported to the Perth area in 2008 and destroyed by burning, which appears to be a successful eradication because no more SHBs have been found in this area since. The only known finding of SHBs in the Northern Territory was one adult found in a queen bee shipment from eastern states in 2010-2011 (N. Annand and R. Spooner-Hart, personal communication).

In Australia, it took about 4 years (2002-2006; P. Neumann, personal observations) before heavy damage occurred to strong colonies (USA only 2 years 1996-1998, Neumann and Elzen 2004). This remarkable time delay compared to the USA might be due to the historic drought that Australia has had at the time (Horridge et al. 2005). A survey in Queensland has shown that more than 3000 hives had been lost to the SHB resulting in economic damage of $\sim \$ 1,200,000$ (Mulherin 2009). Another survey in New South Wales estimates that between 2002 and 2006 alone, more than 4500 honeybee colonies died out due to SHB infestation (Rhodes and McCorkell 2007). This clearly illustrates that SHB has become a serious economic threat to Australian apiculture given suitable conditions, at least in eastern Australia (Annand 2008, 2011b; Spooner-Hart et al. 2016).

\subsubsection{Europe}

Portugal SHBs were intercepted in a shipment of queens into Portugal in 2004 (Murilhas 2004). Larvae were found in queen cages and the rigorous sanitation measures (killing of all bees and destruction of destination apiaries) successfully prevented this introduction (Murilhas 2004; Neumann and Ellis 2008; Valério da Silva 2014), probably because very few specimens were introduced and the detection was early.

Italy In September 2014, SHBs were confirmed in Calabria (Palmeri et al. 2015), where larvae, pupae and adults were found (Mutinelli et al. 2014). So far, 83 infested apiaries were confirmed in Calabria, one in Sicily and an infested feral colony was also found in Gioia Tauro municipality (3 November 2015, Istituto Zooprofilattico Sperimentale delle Venezie 2015). Taken together, these reports indicate that SHBs have been present and reproduced in Italy long before their first detection in September 2014 (Neumann 2016). No cases have been reported between 30 December 2014 and 16 September 2015, but since then, 24 new infested apiaries were officially confirmed in Calabria (3 November 2015, Istituto Zooprofilattico Sperimentale delle Venezie 2015). Hence, despite the comprehensive efforts of the local stakeholders, the chances of SHB establishment in Italy are not zero. Indeed, irrespective of the success of any eradication measure associated with apiculture whatsoever, SHBs are known to be able to survive outside of apiculture.

\subsubsection{Asia}

In June 2014, an SHB outbreak was documented in Lupon, Philippines (Brion 2015). Managed colonies of introduced European honeybees were severely infested, and the majority of them collapsed (Brion 2015). So far, SHBs were not observed in non-managed colonies and the potential impact on native $A$. cerana and stingless bees is currently unknown. Control measures are currently being undertaken, e.g. prohibiting the interisland movement of bees (C. R. Cervancia, personal communication). Data from the Philippines 
are urgently required to evaluate the potential consequences on the unique native bee fauna of Southeast Asia under the local tropical conditions, favouring SHB reproduction.

\subsection{Invasion pathways and origins of invasive populations}

Knowledge about the likelihood of different invasion pathways is essential to limit the further spread of the SHB via adequate legislation and border control measures. SHBs can potentially reach new shores via trade associated with apiculture, including package bees, queen cages, whole honeybee colonies as well as apicultural tools, combs and processed or non-pressed wax. Imports of Bombus spp. and stingless bees might also be an alternative route as well as import of fruits and soil (e.g. for potted plants with soil, FERA 2014; Chauzat et al. 2015). Introductions near major harbours (Charleston, USA, Hood 2000; Gioia Tauro, Italy, Mutinelli et al. 2014) or on islands (Jamaica (FERA 2010), Hawaii (Connor 2011a, b), Cuba (Peña et al. 2014), Philippines (Brion 2015)) indicate that trade via ships may play a role (possibly via fruit import, $\mathrm{H}$. Smith, personal communication).

In almost all cases, migratory beekeeping and or active dispersal of SHB might be involved (Québec, Canada (Evans et al. 2003, 2008; Giovenazzo and Boucher 2010); Coahuila, Mexico (Del Valle Molina 2007)). In Australia, hives that moved from New South Wales into Victoria in 2003 and in Victoria in 2005 as well as from Kimberley to Perth in 2008 were found to be carrying SHB (N. Annand, R. Spooner-Hart, personal communication). In May 2011, adult SHBs were found in a conservation park on the South Australia-Victoria border on illegally moved hives and, in May 2012, SHB beetles and larvae were found in hives and supplementary pollen in close-by Naracoorte, South Australia (N. Annand, R. Spooner-Hart, personal communication). National and international apicultural trade seems to play a key role too (Alberta, Canada, Australian package bees, Lounsberry et al. 2010; Itay-Al-Baroud, Egypt, import of colonies from Ethiopia? A. M. Mostafa, personal communication). Survival of adult and/or immature SHB life stages obviously depends on both storage conditions during transport and food availability. Moreover, inspections prior to and after trade (e.g. border controls) should also be considered. However, rather unlikely routes such as processed wax (Manitoba, Canada, cf. Neumann and Elzen 2004) and queen cages (Portugal 2004: Murilhas 2004; Northern Territory, Australia 2010: R. Spooner-Hart, personal communication) have also been reported, although beetle survival in the former may be compromised and inspections prior to export should be rather efficient in the latter case.

Genetic tools enable to trace back the origin of invasive populations, which can be helpful to better mitigate future introductions. SHB mtDNA sequence analyses of SHBs from the USA and South Africa indicate that the populations on both continents belong to a single species, although it is not clear whether a single or multiple introductions occurred (Evans et al. 2000, 2003). SHBs in Australia have a different origin than beetles in North America and the initial North American beetles shared the same source (Evans et al. 2008; Lounsberry et al. 2010). The outbreaks in Quebec, Canada appear to originate from the USA (Evans et al. 2003, 2008), and all have been found close to the US border. The SHBs confirmed in Alberta (Canada) in 2006 were a new introduction via Australian package bees (Lounsberry et al. 2010).

Taken together, the current evidence clearly shows that international apicultural trade and/or migratory beekeeping were involved in all invasion cases, where clear signs could be found. So far, there is no evidence whatsoever that imports of soil and fruits have resulted in any invasion of this pest. From an economic point of view, it appears therefore prudent to focus on legislation and even stricter control of international bee trade to limit the future global spread of SHBs.

\section{DIAGNOSIS, CONTROL AND PREVENTION}

Efficient diagnostic methods for SHBs are less required in the endemic range, but essential in introduced ones, especially in those which 
are at high risk of introduction (e.g. surrounding new introductions in former SHB-free regions), in order to detect new SHB infestation at an early stage and have a chance to eradicate it. Furthermore, a growing number of countries have installed trade regulations for bees and bee products that depend on the infestation status with $A$. tumida. These countries need to install efficient diagnosis methods into surveillance programs, to declare that they are "SHB-free" and enable trade without restrictions. However, also in areas where A. tumida has already established populations, accurate information on the level of infestation is needed to give beekeepers a measure of the actual SHB infestation of their colonies to make treatment decisions. This is especially true for areas with elevated conditions for SHB reproduction, e.g. tropics in Central and South America and Southeast Asia. For prevention of SHB infestations, beekeepers need to constantly monitor their colonies for the presence of SHBs, maintain strong colonies and keep their facilities clean (Hood 2011). Numerous methods to diagnose and/or control SHB infestation were invented by beekeepers and scientists since the SHB has become an invasive species. In the coming passage and in the Tables IV and V, we will summarize and assess the most important control concepts, methods and inventions.

\subsection{Diagnosis}

Diagnosis of $A$. tumida in the laboratory is either based on morphological criteria (Neumann et al. 2013) or by molecular identification (Evans et al. 2000, 2008; Ward et al. 2007; Lounsberry et al. 2010). The life stages of $A$. tumida are shown in Figure 1. Adult SHBs are 5-7 mm long and 2.5-3.5 mm wide. Head, thorax and abdomen are well separated. Key features of $A$. tumida are its "club-shaped" antennae and its elytra, which are smaller than the abdomen, so the end of the abdomen is exposed. Special attention should be given to body coloration, because freshly emerged adult $A$. tumida look very similar to $C$. luteus (Neumann and Ritter 2004), thereby bearing the possibility of false positive results. SHB larvae grow to $\sim 1-\mathrm{cm}$ long, are creamy white and can easily be distinguished from the wax moth larvae (Galleria mellonella) due to the presence of three pairs of long forelegs, a row of spines on the dorsal side of each body segment and two large spines protruding from the rear and in the field the absence of webbing in the combs.

Several molecular techniques to diagnose SHBs have been described (Table II; Evans et al. 2000, 2008; Ward et al. 2007; Lounsberry et al. 2010). Real-time PCR in conjunction with an automated DNA extraction protocol was used to screen hive debris for the presence of SHBs (Ward et al. 2007). The method was shown to be able to detect DNA from SHB eggs, larvae and adult specimens collected from Africa, Australia and North America and to successfully detect SHB DNA extracted from spiked and naturally infested debris. Evans et al. (2008) described 15 microsatellite loci, which are polymorphic in the native as well as in the introduced ranges of this species, showing from two to 22 alleles. Such polymorphic microsatellite loci for SHB are necessary to map the increase in distributions, but they are also useful to explore the SHB mating system and local gene flow patterns. These loci have also proven useful in mapping the movement of SHBs in the Americas (Lounsberry et al. 2010). Especially if only eggs or larvae are available, the molecular techniques are essential as these live stages are impossible to be diagnosed visually. Another advantage is that samples can be collected over time and as long as they stored appropriate molecular analyses are always possible. For example, screening of hive debris (Ward et al. 2007) was used in a surveillance study in Spain to evaluate the possible presence of SHB in the country (Cepero et al. 2014). However, our limited knowledge of the $A$. tumida genome currently constrains the full diagnostic power of molecular tools. Indeed, limited resolution and false negative results are likely (e.g. using conventional primers; Evans et al. 2008). Therefore, it appears crucial to get the $A$. tumida genome sequenced to foster the usage of molecular tools for both research and diagnostics.

Monitoring of sentinel apiaries that are located in zones at risk for SHB introduction (e.g. seaport or airport) is recommended to detect SHB 
Table IV. Overview of small hive beetle diagnostic methods. None of them have been standardized and only few have been evaluated for their reliability. Please refer to Neumann and Elzen (2004) and Neumann et al. (2013) for further references. Brief descriptions and challenges are given.

\begin{tabular}{|c|c|c|}
\hline Method & Description & Challenges \\
\hline Visual inspections & $\begin{array}{l}\text { Colonies are carefully } \\
\text { examined for the presence } \\
\text { of SHB (Spiewok et al. 2007; } \\
\text { Neumann and Hoffmann 2008; } \\
\text { Mutinelli et al. 2014). A control } \\
\text { to estimate the numbers of } \\
\text { SHB that might be missed } \\
\text { during visual inspections } \\
\text { resulted in an average of } 8.4 \% \\
\text { adults that were not found } \\
\text { (Spiewok et al. 2007) }\end{array}$ & $\begin{array}{l}\text { Thorough screenings are } \\
\text { labour-intensive and } \\
\text { time-consuming (depending } \\
\text { on colony size and experience } \\
\text { of the inspectors). The level } \\
\text { of detail of the inspection } \\
\text { determines its accurateness. } \\
\text { To obtain reliable results, } \\
\text { training is required }\end{array}$ \\
\hline Olfactory inspections & $\begin{array}{l}\text { Heavy SHB infestations } \\
\text { are characterized by a } \\
\text { typical rotten smell, resulting } \\
\text { from fermented honey } \\
\text { (Schäfer and Ritter 2014), } \\
\text { which can be easily recognized }\end{array}$ & $\begin{array}{l}\text { Smell is in general unreliable } \\
\text { and rather unsuitable, especially } \\
\text { because it is subjective and rotten } \\
\text { honey is not always occurring } \\
\text { in infested colonies }\end{array}$ \\
\hline Traps inside colonies & $\begin{array}{l}\text { Diagnostic strips are placed } \\
\text { on the bottom board, by } \\
\text { sliding them through the } \\
\text { entrance. They have a mean } \\
\text { capture efficacy of } 30 \% \text { of } \\
\text { the colony SHB population } \\
\text { (Schäfer et al. 2008; 2010a, b, c). } \\
\text { All kinds of control traps } \\
\text { may be also used for } \\
\text { diagnostics (see Table V) }\end{array}$ & $\begin{array}{l}\text { Sensitivity might be compromised } \\
\text { by screened bottom boards, } \\
\text { cold weather and low } \\
\text { infestation levels and should } \\
\text { be applied in association with } \\
\text { visual inspection (Mutinelli et al. 2014). } \\
\text { Eggs cannot be detected, but } \\
\text { nevertheless, it is a quick approach, } \\
\text { which can be applied in a wide area }\end{array}$ \\
\hline $\begin{array}{l}\text { Baited traps outside } \\
\text { colonies }\end{array}$ & Please refer to Table $\mathrm{V}$ & Please refer to Table $\mathrm{V}$ \\
\hline $\begin{array}{l}\text { Inspection after killing } \\
\text { the colony }\end{array}$ & $\begin{array}{l}\text { The most accurate approach } \\
\text { for counting SHB is to } \\
\text { examine beetles in freshly } \\
\text { killed colonies. One can, } \\
\text { presumably, find } 100 \% \\
\text { of the SHB (all live stages) } \\
\text { inhabiting a colony if all } \\
\text { SHB and bees are dead } \\
\text { (Schäfer et al. 2011; } \\
\text { Neumann et al. 2013) }\end{array}$ & $\begin{array}{l}\text { Even very useful for method } \\
\text { validation (gold standard), } \\
\text { this approach cannot be } \\
\text { widely applied because } \\
\text { it requires destruction of } \\
\text { the entire colony }\end{array}$ \\
\hline Post hoc analyses & $\begin{array}{l}\text { Collapsed or absconded } \\
\text { colonies are characterized } \\
\text { by fermented honey, often } \\
\text { dripping out of hive entrances, } \\
\text { destroyed combs } \\
\text { (Schäfer and Ritter 2014). } \\
\text { Dark, crusty traces from } \\
\text { wandering larvae on the } \\
\text { outside of the hive can be found } \\
\text { (Schäfer and Ritter 2014) }\end{array}$ & $\begin{array}{l}\text { If colonies absconded/died } \\
\text { some time ago, ants and } \\
\text { wax moths may have destroyed } \\
\text { clinical signs inside and } \\
\text { rain/storm outside of hives }\end{array}$ \\
\hline Digging soil & $\begin{array}{l}\text { Soil around infested colonies } \\
\text { can be successfully screened }\end{array}$ & $\begin{array}{l}\text { This is very labour-intensive } \\
\text { and may produce false }\end{array}$ \\
\hline
\end{tabular}


Table IV (continued)

\begin{tabular}{|c|c|c|}
\hline Method & Description & Challenges \\
\hline & $\begin{array}{l}\text { for SHB wandering larvae, } \\
\text { pupae and adults } \\
\text { (Pettis and Shimanuki 2000) }\end{array}$ & $\begin{array}{l}\text { negative results because } \\
\text { wandering larvae } \\
\text { can crawl long distances } \\
\text { (Sanford 1998), low-level } \\
\text { reproduction (Spiewok and Neumann 2006a) } \\
\text { is likely to remain unnoticed } \\
\text { and SHB mass reproduction } \\
\text { occurs only irregularly }\end{array}$ \\
\hline \multicolumn{3}{|c|}{ Molecular } \\
\hline $\begin{array}{l}\text { Screening hive } \\
\text { debris for SHB }\end{array}$ & $\begin{array}{l}\text { Real-time PCR can } \\
\text { be used to screen } \\
\text { hive debris for the } \\
\text { presence of SHB (Ward et al. 2007) }\end{array}$ & \multirow{4}{*}{$\begin{array}{l}\text { Molecular methods require } \\
\text { sophisticated equipment, } \\
\text { and trained personnel. The } \\
\text { experimental setup has to be } \\
\text { validated and in-house and } \\
\text { inter-laboratory comparative } \\
\text { tests should be accomplished } \\
\text { to ensure the accuracy of results. } \\
\text { The limited knowledge of the } \\
\text { SHB genome currently constrains } \\
\text { the full diagnostic power of } \\
\text { molecular tools. False negative } \\
\text { results are not unlikely, e.g. } \\
\text { due to variable primer regions } \\
\text { in different SHB populations }\end{array}$} \\
\hline $\begin{array}{l}\text { Microsatellite } \\
\text { analyses }\end{array}$ & $\begin{array}{l}\text { Microsatellite loci } \\
\text { which are polymorphic } \\
\text { in the native as well as } \\
\text { in the introduced ranges } \\
\text { of SHB were described (Evans et al. 2008). } \\
\text { These loci have also proven } \\
\text { useful in mapping the } \\
\text { movement of SHB in } \\
\text { the Americas (Lounsberry et al. 2010) }\end{array}$ & \\
\hline $\begin{array}{l}\text { Mitochondrial DNA } \\
\text { analyses }\end{array}$ & $\begin{array}{l}\text { Two oligonucleotide primers } \\
\text { that amplify a region of the } \\
\text { SHB mitochondrion } \\
\text { were described (Evans et al. 2000) }\end{array}$ & \\
\hline Sequencing & $\begin{array}{l}\text { Sequences can be aligned } \\
\text { against numerous SHB } \\
\text { haplotypes in public } \\
\text { sequence databases } \\
\text { (Neumann et al. } 2013 \text { ) }\end{array}$ & \\
\hline
\end{tabular}

infestation at an early stage in order to eradicate it (Chauzat et al. 2015), and several countries have initiated this method (Australia (Annand 2011b), Italy (Mutinelli et al. 2014), Switzerland (Elena di Labio, personal communication)). The most rudimentary and time-consuming method to estimate the infestation level of a colony in the field is screening of the entire colony (Spiewok et al. 2007; Neumann and Hoffmann 2008). However, this method is also highly accurate, if done by specially trained personnel and therefore the method of choice for new introductions with low infestation rates. A very fast, cheap and easy quantitative diagnosis for SHB in the field is the use of diagnostic strips made of corrugated plastic (Schäfer et al. 2008, 2010a), which are placed on the bottom board via the entrance, without the need to open or manipulate the colonies. A test at five apiaries in Richmond, NSW, Australia showed that the number of SHBs found in the transparent strips correlated significantly with the total number of SHBs in the hives (detected by screening of the entire colony), and the average efficacy was $34.5 \%$ (Schäfer et al. 2008). It is recommended to leave the diagnostic strips inside the colonies for at least $48 \mathrm{~h}$ to give the beetles a chance to find the refuges and it is not recommended to use them during cold seasons, when bees form winter clusters, because adult SHBs might leave the bottom board seeking shelter in bee clusters (Figure 3; Pettis and Shimanuki 2000). 
Table V. Overview of small hive beetle control methods. None of the methods have been standardized and only few have been evaluated for their efficacy. Please refer to Neumann and Elzen (2004) and Neumann et al. (2013) for further references. Brief descriptions and challenges are given.

Method Description Challenges

In hives

Manual removal

Kitchen cleaning wipes

Traps for adults

(a) Bottom boards

(b) Between top bar frames

(c) Instead of frames

(d) Modified bottom boards
Sucking aspirators (exhausters, pooters) are used to manually remove SHB adults and larvae (Spiewok et al. 2007, 2008; Neumann and Hoffmann 2008).

Kitchen cleaning wipes are placed on top of the frames, where they are shred into fibres by the bees and the beetles become trapped in the fibrous material (Zacchetti 2015)

Exploit adult SHB thigmotaxis and/or harassment by bees. Small openings $(\sim 3 \mathrm{~mm})$ exclude bees but allow SHB to hide inside

SHB come in contact with killing agents placed onto the bottom board, e.g. with CheckMite $+{ }^{\mathrm{TM}}$ strips (Ellis and Delaplane 2007;

Neumann and Hoffmann 2008; Bernier et al. 2015); fipronil (Levot 2008); diatomaceous earth (Buchholz et al. 2009; Cribb et al. 2013) or entomopathogenic fungi (Ellis et al. 2004e)

Small containers (usually filled with oil), which lids have openings that allow SHB to enter are placed on top of the frames, e.g. Beetle Eater $^{\mathrm{TM}}$ with oil (Bernier et al. 2015), with diatomaceous earth (Cribb et al. 2013); Beetle Blaster $^{\mathrm{TM}}$ (Mutinelli et al. 2014)

The Hood Trap ${ }^{\mathrm{TM}}$ attaches to a frame and has 3 compartments for attractant and/or killing liquids (Hood 2006, 2009; Nolan and Hood 2008, 2010; Bernier et al. 2015)

Devices with screened or tubed anti-Varroa bottom board (Keshlaf and Spooner-Hart 2013) and with slatted (e.g. West Trap ${ }^{\mathrm{TM}}$ ), screened (Freeman Beetle Trap ${ }^{\mathrm{TM}}$ Freeman 2009; Harman 2005; Hood 2011) or a baited bottom board trap with oil-filled container underneath (Torto et al. 2007b) replace the regular bottom board
Very labour-intensive. Works best with two persons, one working the colony and the other collecting SHB.

Efficacy might be compromised (see Table IV). Keeping colonies open for long time may promote robbing

The authors have no experience with this very economical method yet

SHB may hide elsewhere. Bees may close the openings with propolis or wax and the containers have to be checked periodically and exchanged when sealed and/or crowded (Bernier et al. 2015)

During cooler weather, adult SHBs tend to leave the bottom boards (Schäfer et al. 2011). Chemicals can have a high efficacy (possibly up to $100 \%$, Levot 2008, 2012) but should not be used prior to honey harvest (possible residues). Chemicals used in traps are potentially spread to honeybees with side effects on bees. Resistant SHB strains may develop as in the case of $V$. destructor mites (Spreafico et al. 2001)

Pending weather and colony conditions, majority of adult SHB tend to stay on bottom boards (Neumann and Hoffmann 2008; Torto et al. 2010a). Needs to be positioned next to brood nest to be more effective and efficacy is not known (Bernier et al. 2015)

The Hood Trap ${ }^{\mathrm{TM}}$ requires replacing one frame and creates empty space in the frame around the trap. Efficacy is not known (Bernier et al. 2015)

Hives have to be even standing because the oil may otherwise spill over. Some of these traps require modification and are not for use with screened bottom boards 
Table V (continued)

\begin{tabular}{lll}
\hline Method & Description & Challenges \\
\hline
\end{tabular}

Traps for larvae

Modified entrances

Killing the entire colony

Outside of hives

Baited traps

UV lights to attract SHB wandering larvae in honey houses

Sterile insect technique
Traps in front of hive entrances intercept wandering larvae as they exit the hive for pupation in the soil (Arbogast et al. 2012)

Wooden entrance reducers (Frake et al. 2009) or upper hive entrances (Ellis et al. 2002a; Hood 2004; Hood and Miller 2005) are installed to limit invasion success of intruding SHB

Destruction of infested colonies (Murilhas 2004; Neumann and Hoffmann 2008; Mutinelli et al. 2014; Perth Australia, 2008, N. Annand and R. Spooner-Hart, personal communication)

Baited pole traps (Arbogast et al. 2007, 2009a) are placed at the bee yard. As bait, a combination of honey, pollen, brood and adult bees (cf. Neumann and Elzen 2004) or pollen dough, inoculated with the yeast Kodamaea ohmeri (Torto et al. 2007a, b, 2010a), is used. White traps captured more SHB than black ones and most SHB were caught, when traps were positioned at the same height as the hive entrance (de Guzman et al. 2011)

Lights are placed close to the ground in the honey house to attract positive phototactic wandering larvae (cf. Neumann and Elzen 2004; Duehl et al. 2012). The highest response of SHB larvae and adults was shown to UV light with $390 \mathrm{~nm}$ wavelength (Duehl et al. 2012)

Male SHBs are laboratory-reared, radiated for sterilisation and released (Downey et al. 2015; Neumann et al. 2016a)
Small number of larvae caught in lowlevel reproduction (Arbogast et al. 2012). Occurrence of SHB mass reproduction is often unpredictable. If larvae emigrate, the damage to the colony has already happened. The trap is recommended primarily as a research tool for SHB population dynamics

SHBs usually enter colonies without problems (Lundie 1940), but less adult SHBs were reported from colonies with upper hive entrances (Ellis et al. 2002a) or entrance reducers (Frake et al. 2009). Hood and Miller (2005) found no significant effects of upper hive entrances. Bees may also be affected, e.g. reduced brood in colonies having an upper hive entrance (Hood and Miller 2005)

This probably is the most efficient control as evidenced by the Portugal (Murilhas 2004) and Perth cases (N. Annand and R. Spooner-Hart, personal communication), but both the bee colonies and the hive materials get lost

As these traps generally do not catch high numbers of beetles, further bait improvements are necessary as yet no bait was found to be more attractive than a honeybee colony. Catch numbers also depend on environmental conditions as more SHB move out of the hive in hot summer conditions (Annand 2011a). Nevertheless, they are a quick approach which can be applied in a wide area

If wandering larvae are observed in the honey house, the larvae have already done their damage in the colonies, but light shows promise for SHB control in all locations where comb is stored or honey extracted

Doses required obtaining SHB male sterility (>75 Gy) resulted in $100 \%$ mortality after 7 days (Neumann et al. 2016a). Irradiation of prereproductive adults of both sexes at 
Table V (continued)

\begin{tabular}{|c|c|c|}
\hline Method & Description & Challenges \\
\hline & & $\begin{array}{l}45 \text { Gy under low oxygen }(1-4 \%) \\
\text { caused a high level of sterility } \\
(>99 \%) \text { while maintaining moderate } \\
\text { survivorship for several weeks, which } \\
\text { might suffice for sterile insect releases } \\
\text { (Downey et al. 2015). However, SHB } \\
\text { mating system (Mustafa 2015) may } \\
\text { reduce chances of success }\end{array}$ \\
\hline
\end{tabular}

Soil

Concrete

Drenching

Slaked lime and diatomaceous earth

Natural enemies

Removal
Hives are set on concrete grounds to prevent pupation in the soil as the wandering larvae cannot penetrate the concrete surface

The soil around infested colonies is drenched with pesticides (pyrethroids) to kill all live stages of SHB (Hood 2000, 2011; Mutinelli 2014). It is recommended to treat the area within a radius of $0.90-1.80 \mathrm{~m}$ around the hive (Pettis and Shimanuki 2000)

Mixtures of soil with slaked lime or diatomaceous earth should prevent pupation due to dehydration. Slaked lime reduced the reproductive success of SHB only in high dosages (10 and $15 \mathrm{~g} / 100 \mathrm{~g}$ soil) and diatomaceous earth only in the most hydrophobic formulation (Buchholz et al. 2009)

Entomopathogenic fungi or nematodes are applied to the soil surrounding infested colonies to kill all SHB life stages (Richards et al. 2005; Cabanillas and Elzen 2006; Muerrle et al. 2006; Leemon and McMahon 2009; de Guzman et al. 2009; Ellis et al. 2010). Metarhizium added to soil killed large proportions of larvae in the soil (Leemon 2012). Recently, the nematodes Steinernema carpocapsae and $S$. kraussei were shown to provide $100 \%$ mortality of larvae pupating in sand pots (Cuthbertson et al. 2012). It is recommended to treat the area within a radius of $0.90-1.80 \mathrm{~m}$ around the hive (Pettis and Shimanuki 2000)

The top soil layer of infested apiaries is removed and treated or deep buried into the ground (Murilhas 2004)
Efficacy is probably low because SHB wandering larvae are able to migrate long distances (>200 m, Somerville 2003; Hood 2011)

Pyrethroids can harm bees and other non-target insect species. Therefore, they should only be used when SHB larvae are in the colony as it is not known how long pyrethroids remain lethal to SHB in the soil. Moreover, resistant SHB strains may develop

Efficacy of slaked lime or diatomaceous earth against the soil dwelling stages of SHB in the field is unknown, as only laboratory experiments were conducted so far

Generally, these soil treatments are only effective when timed appropriate to when larvae are migrating (Pettis and Shimanuki 2000), but SHB mass reproduction is unpredictable and usually only few larvae leave the colonies (Spiewok and Neumann 2006a; Neumann and Hoffmann 2008; Arbogast et al 2010). Since nematodes are susceptible to dehydration, preventive treatment might be less efficient, but no field data are available

As this requires heavy equipment or is very labour-intensive, it is recommended only after entire apiary destruction
The most accurate diagnosis method is to kill the entire colony with bees and the pest followed by a visual inspection, including dissection of each frame (Neumann and Hoffmann 2008; Neumann et al. 2013). However, this can of course not be applied systematically in the field. 
Nevertheless, this method seems to be "gold standard", because its efficacy is virtually $100 \%$ if applied correctly and can thus be used to validate other diagnostic methods. It could also be applied for wild swarms and other research purposes.

\subsection{Control}

Efficient control of SHBs should not rely on a single method; it requires pest management decisions based on adequate diagnosis methods to assess which control measures will lead to maximum efficacy and simultaneously produce results with the fewest environmental impacts. Integrated pest management (IPM) should be considered (Ellis 2005a, b; Hood 2011), using a combination of all available control methods (mechanical, biological and chemical) in a responsible matter. Manual removal of SHBs (screening of entire colonies, see above) could also be regarded as a control option, but it is very labour-intensive. Different kinds of SHB traps can be installed in or outside of the colonies that should be checked regularly during apiary visits. The functional principle of most SHB traps is creating a refuge or space, which is large enough for SHBs and too small for bees to pass through at once to enter the trap which contains a reservoir for the killing product (veterinary medicine, oil, diatomaceous earth, etc.). Another way of trapping is currently in use in Australia, where kitchen cleaning wipes, placed on top of the frames, are shred into fibres by the bees and the beetles become trapped in the fibrous material (Zacchetti 2015).

Among the products that are used to control $V$. destructor mites, CheckMite $+{ }^{\mathrm{TM}}$ strips were shown to also have broad toxicity against SHBs, killing both larvae and adults, when placed underneath corrugated cardboard or plastic sheets on the bottom board (Ellis and Delaplane 2007; Neumann and Hoffmann 2008). However, when wandering larvae were exposed to CheckMite $+{ }^{\mathrm{TM}}$ for $24 \mathrm{~h}$, they still burrowed successfully, which will minimize the efficacy to control SHB larvae in the field (Ellis and Delaplane 2007). Another easy to install bottom board trap (Beetle Barn ${ }^{\mathrm{TM}}$ with CheckMite $+{ }^{\mathrm{TM}}$ ) also showed high efficacy against adult SHBs and the position of the trap, whether in the front or the back of the bottom board, had no effect on the number of captured SHBs (Bernier et al. 2015). In Australia, a refuge trap was developed comprising of two-piece rigid plastic shells encasing a fipronil-treated corrugated cardboard (Apithor ${ }^{\mathrm{TM}}$ ) insert (Levot 2008; Levot and Somerville 2012). In a 36-day-long field trial conducted in a beetle-infested apiary at Richmond, NSW, Australia, live adult beetles were eliminated from hives containing Apithor ${ }^{\mathrm{TM}}$ while beetle numbers increased by approximately $20 \%$ in co-located control hives The residues in honey ripened inside the test hives over 1 month while the devices were in place did not exceed $1 \mu \mathrm{g} / \mathrm{kg}$, and no ill effects on the bees were observed (Levot 2012). Despite earlier observations of lively SHBs emerging from a hive, unscathed by a formic acid treatment (Amrine and Noel 2006), Schäfer et al. (2009) tested the effects of formic (60\%) and acetic acid (70\%) treatments on SHB in nucleus boxes with two honey/pollen frames each. Formic acid decreased the number of SHB larvae-infested areas on the combs, and acetic acid treatments showed higher SHB adult mortality compared to controls (Schäfer et al. 2009). However, further evaluation of evaporating formic acid in field colonies did not significantly increase mortality in SHBs, and thus neither formic nor acetic acid treatments are suitable to control SHBs (Buchholz et al. 2011).

Kanga and Somorin (2011) assessed the susceptibility of SHBs to 14 selected insecticides and four insect growth regulators in the laboratory. Their results indicated that SHBs are selectively susceptible to several classes of insecticides. Chemicals are always the first choice in controlling a new pest because they are mostly easy to use and effective, but there are reported problems, for example with the residues of coumaphos present in wax (Mullin et al. 2010), which can contaminate honey and besides the product does not seem to work well in cooler temperatures (Mostafa and Williams 2000). Moreover, SHBs may develop resistance to any chemical used for their control because of their high mobility and fecundity (De Guzman et al. 2011). In conclusion, chemicals are fraught with difficulties in the end.

A diverse range of alternatives to chemical control have been developed and tested in laboratory and field assays. There have been mixed 
results with alternations of the hive entrance. The use of entrance reducers had a significant effect on the average number of invading SHBs (Frake et al. 2009), whereas an upper hive entrance was not effective against SHB invasion and resulted in a reduction in bee brood, demonstrating their infeasibility (Hood 2004; Hood and Miller 2005). The use of slaked lime and diatomaceous earth was tested in the laboratory and in honeybee field colonies (Buchholz et al. 2009). In diagnostic tray traps in the field, about a third of the adults of infested colonies were caught with slaked lime and diatomaceous earth (Fossil Shield ${ }^{\circledR}$ FS 90.0s) and caused $100 \%$ adult mortality inside the traps, where more than $50 \%$ died within $48 \mathrm{~h}$ (Buchholz et al. 2009). Cribb et al. (2013) performed laboratory tests with diatomaceous earth as killing agent inside top frame bar traps (Beetle Eater $^{\mathrm{TM}}$ ) and reported $100 \%$ SHB mortality compared to $8.6 \%$ mortality in controls without diatomaceous earth. In these and similar traps (Beetle Blaster $\left.^{\mathrm{TM}}\right)$, the reservoirs are usually filled with oil, in which entering SHBs eventually drown (Bernier et al. 2015) which is also the case in many bottom board traps (e.g. West Trap ${ }^{\mathrm{TM}}$, Freeman Beetle Trap $^{\mathrm{TM}}$ ). A bait, consisting of pollen dough (mixture of pollen and honey) that was conditioned either by the feeding of adult SHBs or by inoculation with the yeast $K$. ohmeri (Benda et al. 2008), has been used successfully in bottom board traps in the USA and Kenya to monitor SHB populations (Torto et al. 2007b, 2010a).

All these traps only provide adequate control when the position of the trap in the hive is adapted to the environmental situation. This is important, as the bottom board is a suitable location for SHB traps during the hot season, but during the winter, SHB will be found close to or among heat-producing clustering bees (Schäfer et al. 2011). At present, in-hive control devices appear to be most appropriate for removal of SHBs (Annand 2011b). Traps that capture wandering larvae at a colony scale (Arbogast et al. 2012) are recommended primarily as research tools (Neumann et al. 2013), as damage has already occurred when wandering larvae leave the colonies.
When reproduction has occurred, SHB larvae and pupae may be present in the soil around the hive. Since the pyrethroid permethrin (in the USA sold as $\operatorname{GardStar}^{\circledR}$ ) applied around colonies achieved some success at killing beetle larvae and pupae (cf. Neumann and Elzen 2004), pyrethroid ground drenching is widely used for SHB control (e.g. cypermethrin and tetramethrin were used in Italy; Mutinelli et al. 2014), but there are also problems with the use of ground drenches. They may protect individual hives on site but do little to prevent the spread of SHBs (Hood 2000), and they need to be applied around the hives in all directions (about 180-360 $\mathrm{cm}$ ) to maximize their efficacy (Pettis and Shimanuki 2000). Moreover, during the reproductive season of SHBs, larvae are continuously leaving the hives to pupate in the ground (Torto et al. 2010a), which makes continuous treating necessary.

Three different light types (white bulb, black light insect light) were tested as attractants, indicating that none of these light sources are attractive to adult SHBs (Neumann and Elzen 2004). But lights have been used successfully in the honey house to attract wandering larvae, as they are positively phototactic (Somerville 2003).

Flying SHBs have been monitored with baited traps (cf. Neumann and Elzen 2004). The traps were baited with honey, pollen, brood and live adult honeybees in several compositions to test their attractiveness to SHBs. But as beetles could enter and then escape, these traps were ineffective for control. Later, Arbogast et al. (2007) used refined traps that lure and capture SHBs using a bait consisting of pollen dough (mixture of pollen and honey) conditioned by allowing male SHBs to feed on it for 3 days were tested successfully in the field. In their study, they also found that significantly more SHBs were captured if the traps were located in the shade compared to sunny locations (Arbogast et al. 2007). Torto et al. (2007a) tested the attractiveness of the same diet inoculated with the yeast $K$. ohmeri, isolated from the beetle. Further tests with $K$. ohmeri-inoculated pollen dough-baited 
traps confirmed the positive influence of shade and showed a negative correlation with distance to bee hives on the frequency of capture (Arbogast et al. 2009a). To investigate the response of adult $A$. tumida to visual stimuli, de Guzman et al. (2011) tested the influence of black and white colour and the height on pole trap efficiency. The average catch in white traps was significantly higher than that of black traps, probably because white is more reflective than black, and traps positioned at the same height as colony entrances showed the highest catch numbers in the field. As these traps generally do not catch high numbers of beetles and honeybee hives seem to lure the majority of the beetles, further improvements are necessary (de Guzman et al. 2011), e.g. capturing and killing SHBs prior to hive entry will bear obvious advantages. Using external baited lures throughout the peak movement times (autumn and spring), capturing SHBs outside of the hives when flying into apiaries may provide a safe, easy control option (Annand 2011b). Such traps would be especially useful if we aim to control SHB numbers outside of managed apiaries, e.g. to safeguard bumblebees and stingless bees as well as wild or feral honeybees. In conclusion, these traps allow continuous observations that provide a relative measure of $A$. tumida migration (Neumann et al. 2013), and there is still hope to develop a lure that is more attractive to SHBs than the colonies of honeybees or other bees.

\subsection{Prevention}

Good beekeeping management is an essential tool in the fight against SHB damage (Westervelt 2005; Hood 2011). As the larval stage is most harmful to the colonies, measurements should be focused on limiting the reproductive success of $A$. tumida in the colony. If strong colonies are infested, the adult beetles are pursuing a "sit-and-wait" reproductive strategy (see above), as they are confined by guard bees or hiding from the bees in areas of the colony, where food for larvae is rare. Only if the situation changes and the beetles are free from captivity do they take the chance and try to lay eggs close to food. Especially if working on the hive creates a narrow space that is secured from bee aggression and pollen or brood is available. This could happen for example when there is no bee space between two brood combs. The impact of the apiary location in the shade or in the sun is unclear. While Arbogast et al. (2007, 2009a) found more SHBs in lured traps outside hives in the shade, Ellis and Delaplane (2006) found that the location in a shaded area or in an open field with full sun had no significant effect on the number of SHB entering the colonies. In Australia, large beekeeping operations around Sydney moved their operations over the Blue Mountains where conditions are cooler and less humid, which has proven the most effective SHB management strategy (N. Annand and R. Spooner-Hart, personal communication).

If honey is harvested, the SHB eggs and larvae on such combs are released from the bees and free to develop; therefore, it is recommended to extract the honey immediately (at least within 2 days) and if this is not possible cold storage or at low relative humidity should be considered as temperatures below $15{ }^{\circ} \mathrm{C}$ and relative humidity less than $34 \%$ prevented egg survival (Annand 2011b). Hives where bees do not exhibit good hygienic behaviour (attempt to remove beetle adults or larvae) should be re-queened or replaced with bees that do (Fletcher and Cook 2005). Feeding pollen substitute patties is problematic as enhanced SHB reproduction may occur (Westervelt et al. 2001), but in winter the risk is lower, as then the conditions are unfavourable for SHBs (Hood 2009). Some beekeepers in the USA use small colonies (nucleus) with Checkmite $+{ }^{\mathrm{TM}}$ strips as death traps for SHBs, believing that small colonies may be especially attractive to them (Jacobson 2005). However, there is no evidence for smaller or queenless colonies being more attractive (Spiewok et al. 2007; Annand 2011a). Nevertheless, it was shown that SHB levels, which are harmless to full-sized colonies, may have an impact on smaller ones (Annand 2011a; Mustafa et al. 2014). As hives containing very low bee numbers are vulnerable to SHB reproduction and subsequent damage, 
beekeepers need to regularly check and remove hives that are weak or declining. Removing susceptible hives will reduce opportunities for SHB reproduction and, therefore, help to minimize population expansion within the apiary (Annand 2011b).

\section{DISCUSSION}

The introduction of $A$. tumida in areas as far from its endemic range as North America, Australia, Europe and Asia illustrates the high anthropogenic transportation potential of this beetle. However, it appears difficult to trace back the actual transport mechanism into specific areas, especially if introduction is only detected after secondary spread. It seems plausible to assume that the import of package bees, honeybee and bumblebee colonies, queens, hive equipment and/or even soil (Brown et al. 2002) constitutes potential invasion pathways of the SHB. Nevertheless, at the current state of evidence, it is still unclear how SHBs actually reached Australia and the USA. The migratory nature of beekeeping is probably the greatest contributor of SHB transmission within its new ranges (USA: Neumann and Elzen 2004; Australia: Gordon et al. 2014; Annand 2011b). The pattern of SHB spread is probably dominated by long-distance jump dispersal as in other invasive species (Nentwig 2007). Detailed data and comparative studies on the invasion dynamics in the new ranges seem necessary to evaluate the contribution of individual processes to the spread of A. tumida and to improve the predictive power of future modelling efforts. Such studies are however still lacking.

The environmental requirements of SHBs are readily met within a large range of the global distribution of $A$. mellifera both in terms of survival and completion of its life cycle. Indeed, SHBs can establish populations in temperate regions due to their overwintering capacity in the honeybee cluster (Schäfer et al. 2011; Atkinson and Ellis 2012). The requirement for lighter sandy soils during pupation can also be met within many areas. Thus, it is likely that, if introduced, SHBs would swiftly become established in most of the range of the Western honeybee with major implications for apiculture and wild bees under suitable environmental conditions. Also, the ability of SHBs to heavily infest the protected environment of honey houses may allow severe economic damage in any location worldwide similar to the USA and Australia.

Our limited knowledge still constrains our ability to pinpoint the most important factors in SHB reproductive success, e.g. the role of alternative food sources such as fruits remains unclear so far. Many of the behavioural mechanisms have only been qualitatively described or have not been tested in comparative studies between African and European honeybees. Moreover, very important basic features like the number of SHB offspring per social bee colony and levels of infestation of wild/feral African and European honeybee, Bombus spp. and stingless bee host populations have not been rigorously quantified yet. Therefore, more comparative studies between SHBs and social bee host populations in the endemic and new ranges are urgently required.

\section{CONCLUSION}

Since 1996, SHBs have become a global threat to both apiculture and wild bee populations. Despite comprehensive efforts, it will continue to spread. Its future impact will most likely be more severe in areas with managed and feral European-derived honeybee populations as well as warm and humid climate, both fostering SHB population buildup (Neumann 2016). Particular concern should be addressed to beekeeping and native bee fauna in South America, Southeast Asia and the Mediterranean, and we hope that the overview provided here will foster adequate SHB mitigation. However, our knowledge of biology, diagnosis, control and prevention of this pest is still limited, creating demand for more research on SHBs. 


\section{ACKNOWLEDGMENTS}

We wish to thank Nicholas Annand, Alexander Kirejtshuk and an anonymous referee for constructive comments, Wolfgang Nentwig for stimulating discussions as well as Daniel Schläppi for editing an earlier version of the manuscript. Bram Cornelissen and Loris Gbedjissi kindly provided unpublished information. We are particularly grateful to Nicholas Annand, Cleofas R. Cervancia, Lilia de Guzman, Danielle Downey, Rafael A. Caldéron Fallas, Pierre Giovenazzo, Yasser Ibrahim, Natalia Escobedo Kenefic, Alejandro Nicol, Antoine Milhau, Hug Smith and Robert SpoonerHart for detailed updates from Australia, Canada, Egypt, Hawaii, Jamaica, the Philippines and Central America. Financial support was granted by the Vinetum Foundation to PN.

\section{OPEN ACCESS}

This article is distributed under the terms of the Creative Commons Attribution 4.0 International License (http://creativecommons.org/licenses/by/4.0/), which permits unrestricted use, distribution, and reproduction in any medium, provided you give appropriate credit to the original author(s) and the source, provide a link to the Creative Commons license, and indicate if changes were made.

Quo vadis Aethina tumida? Biologie et contrôle du petit coléoptère des ruches

Apis mellifera/Aethina tumida/ abeilles sauvages/ espèce invasive/ ennemis naturels

Wohin gehst du Aethina tumida? Biologie und Kontrolle der Kleinen Beutenkäfer

Apis mellifera / Aethina tumida / Bienen / invasive Art / Kleiner Beutenkäfer

\section{REFERENCES}

Akinwande, K.L., Badejo, M.A., Ogbogu, S.S. (2013) Challenges associated with the honey bee (Apis mellifera adansonii ) colonies establishment in south western Nigeria. Afr. J. Food Agric. Nutr. Dev. 13 (2), $7467-7484$

Amrine J.W., Noel R. (2006) Formic acid fumigator for controlling honey bee mites in bee hives, Virginia Agricultural and Forestry Experiment Station,
Scientific Article Number 2952 [online] http:// www.wvu.edu/ agexten/varroa/FormicAcid.pdf (Accessed on 12 June 2015)

Annand N. (2008) Small hive beetle management options, Primefacts, NSW DPI, 764, 1-7. https:// www.dpi.nsw.gov.au/_data/assets/pdf_file/0010/ 220240/small-hive-beetle-management-options.pdf (Accessed on 10 June 2015)

Annand N. (2011a) Small hive beetle biology, RIRDC, 11(044), 1-58. https://rirdc.infoservices.com.au/downloads/11-044 (Accessed on 10 June 2015)

Annand N. (2011b) Investigations of small hive beetle biology to develop better control options. MSc thesis, University of Western Sydney, Australia

Arbogast, R.T., Torto, B., Van Engelsdorp, D., Teal, P.E. (2007) An effective trap and bait combination for monitoring the small hive beetle, Aethina tumida (Coleoptera: Nitidulidae). Fla. Entomol. 90 (2), 404-406

Arbogast, R.T., Torto, B., Teal, P.E. (2009a) Monitoring the small hive beetle Aethina tumida (Coleoptera: Nitidulidae) with baited flight traps: effect of distance from bee hives and shade on the numbers of beetles captured. Fla. Entomol. 92 (1), 165-166

Arbogast, R.T., Torto, B., Williams, S., Teal, P.E. (2009b) Trophic habits of Aethina tumida (Coleoptera: Nitidulidae): their adaptive significance and relevance to dispersal. Environ. Entomol. 38(3), 561-568

Arbogast, R.T., Torto, B., Teal, P.E. (2010) Potential for population growth of the small hive beetle Aethina tumida (Coleoptera: Nitidulidae) on diets of pollen dough and oranges. Fla. Entomol. 93 (2), 224-230

Arbogast, R.T., Torto, B., Willms, S., Fombong, A.T., Duehl, A., Teal, P.E. (2012) Estimating reproductive success of Aethina tumida (Coleoptera: Nitidulidae) in honey bee colonies by trapping emigrating larvae. Environ. Entomol. 41 (1), 152-158

Arias H.D.M. (2014) Small hive beetle infestation (Aethina tumida), El Salvador, OIE report, [online] http:// www.oie.int/wahis_2/public/wahid.php/Reviewreport/ Review?page_refer = MapFullEventReport\&reporti$\mathrm{d}=14907$ (Accessed on 12 April 2015)

Atkinson, E.B., Ellis, J.D. (2011) Honey bee, Apis mellifera L., confinement behavior toward beetle invaders. Insect. Soc. 58 (4), 495-503

Atkinson, E.B., Ellis, J.D. (2012) Temperature-dependent clustering behavior of Aethina tumida Murray in Apis mellifera L. colonies. J. Insect Behav. 25 (6), 604-611

Benda, N.D., Boucias, D., Torto, B., Teal, P. (2008) Detection and characterization of Kodamaea ohmeri associated with small hive beetle Aethina tumida infesting honey bee hives. J. Apic. Res. Bee. World. 47 (3), 194-201

Bernier, M., Fournier, V., Giovenazzo, P. (2014) Pupal Development of Aethina tumida (Coleoptera: Nitidulidae) in Thermo-Hygrometric Soil Conditions Encountered in Temperate Climates. J. Econ. Entomol. 107 (2), 531-537

Bernier, M., Fournier, V., Eccles, L., Giovenazzo, P. (2015) Control of Aethina tumida (Coleoptera: Nitidulidae) using in-hive traps. Can. Entomol. 147 (01), 97-108 
Berry J. (2009) Small hive beetle round-up/Beetles come on strong in the south right now-be ready! Bee Cult. 38-40. http://www.ent.uga.edu/bees/personnel/documents/Berry1009.pdf (Accessed 10 June 105)

Bezabih, G., Adgaba, N., Hepburn, H.R., Pirk, C.W.W. (2014) The territorial invasion of Apis florea in Africa. Afr. Entomol. 22 (4), 888-890

Borroto H., Chan S., Demedio J. (2014) Diagnóstico de Aethina tumida Murray (Coleoptera: Nitidulidae) en colmenas (Apis mellifera L.) de Mayabeque, Memorias Jornadas Científicas por el 122 Aniversario del Sabio de la Medicina Veterinaria Cubana Dr. Ildefonso Pérez Vigueras, Universidad de Ciencias Médicas - Consejo Científico Veterinario. Pinar del Río, Cuba, 2014

Brion A.C.B. (2015) Small hive beetle poses threat to bee industry. The Philippine Star, [online] http:// www.philstar.com/agriculture/2015/02/22/1426217/ small-hive-beetle-poses-threat-bee-industry (Accessed on 09 June 2015)

Brown, M.A., Thompson, H.M., Brew, M. (2002) Risks to UK beekeeping from the parasitic mite Tropilaelaps clareae and the small hive beetle, Aethina tumida. Bee. World. 83, 151-164

Buchholz, S., Neumann, P., Merkel, K., Hepburn, H.R. (2006) Evaluation of Bacillus thuringiensis Berliner as an alternative control of small hive beetles, Aethina tumida Murray (Coleoptera: Nitidulidae). J. Pest. Sci. 79, 251-254

Buchholz, S., Schäfer, M.O., Spiewok, S., Pettis, J.S., Duncan, M., Ritter, W., Spooner-Hart, R., Neumann, P. (2008) Alternative food sources of Aethina tumida (Coleoptera: Nitidulidae). J. Apic. Res. Bee. World. 47 (3), 201-208

Buchholz, S., Merkel, K., Spiewok, S., Pettis, J.S., Duncan, M., Spooner-Hart, R., Ulrichs, C., Ritter, W., Neumann, P. (2009) Alternative control of Aethina tumida Murray (Coleoptera: Nitidulidae) with lime and diatomaceous earth. Apidologie 40 (5), 535-548

Buchholz, S., Merkel, K., Spiewok, S., Imdorf, A., Pettis, J.S., Westervelt, D., Ritter, W., Duncan, M., Rosenkranz, P., Spooner-Hart, R., Neumann, P. (2011) Organic acids and thymol: unsuitable for alternative control of Aethina tumida (Coleoptera: Nitidulidae)? Apidologie 42 (3), 349-363

Byers, J.A. (1989) Chemical ecology of bark beetles. Experientia 45, 271-283

Cabanillas, H.E., Elzen, P.J. (2006) Infectivity of entomopathogenic nematodes (Steinernematidae and Heterorhabditidae) against the small hive beetle Aethina tumida (Coleoptera: Nitidulidae). J. Apic. Res. Bee. World. 45(1), 49-50

Calderón Fallas, R.A., Arce, H., Ramírez, J.F. (2006) The small hive beetle Aethina tumida Murray, an important problem affecting honey bees. Rev. Cienc. Vet. 24(1), $49-55$

Calderón Fallas, R.A., Montero, M.R., Arias, F.R., Villagra, W.V. (2015) Primer reporte de la presencia del pequeño escarabajo de la colmena Aethina tumida, en colmenas de abejas africanizadas en Nicaragua. Rev. Cienc. Vet. 32 (1), 29-33

Cepero A., Higes M., Martínez-Salvador A., Meana A., Martín-Hernández R. (2014) A two year national surveillance for Aethina tumida reflects its absence in Spain. BMC Res. Notes, 7(878)

Chauzat M.P., Laurent M., Brown M., Kryger P, Mutinelli F., Roelandt S., Roels S., van der Stede Y., Schäfer M., Franco S., Duquesne V., Rivière M.P., Ribière-Chabert M., Hendrikx P. (2015) Guidelines for the surveillance of the small hive beetle (Aethina tumida) infestation, European Union Reference Laboratory for honeybee health (EURL), Anses, pp. 19. https://sites.anses.fr/en/system/ files/Guidelines_SHB_survellance_EURL.pd (Accessed on 10 June $201 \overline{5}$ )

Clay, H. (2006) Small Hive Beetle in Canada. Hivelights 19, 14-16

Connor, L. (2011a) Wipe out! The Big Island In Crisis. Bee. Cult. 139, 55-60

Connor, L. (2011b) The big island in crisis: part two of the small hive beetle story in Hawaii. Bee. Cult. 140, 23-27

Cribb, B.W., Rice, S.J., Leemon, D.M. (2013) Aiming for the management of the small hive beetle, Aethina tumida, using relative humidity and diatomaceous earth. Apidologie 44 (3), 241-253

Cuthbertson, A.G.S., Mathers, J.J., Blackburn, L.F., Powell, M.E., Marris, G., Pietravalle, S., Brown, M.A., Budge, G.E. (2012) Screening commercially available entomopathogenic biocontrol agents for the control of Aethina tumida (Coleoptera: Nitidulidae) in the UK. Insects 3 (3), 719-726

Darias J.L.M. (2014) Small hive beetle infestation (Aethina tumida), Cuba. OIE report. http://www.oie.int/ wahis_2/public/wahid.php/Reviewreport/ Review?page_refer=MapFullEventReport\&reporti$\mathrm{d}=15673$ (Accessed 14 April 2015)

de Graaf D.C.:, Alippi A.M., Antúnez K., Aronstein K.A., Budge G., De Koker D., De Smet L., Dingman D.W., Evans J.D., Foster L.J., Fünfhaus A., Gonzalez E.G., Gregorc A., Human H., Murray K.D., Nguyen K.B., Poppinga L., Spivak M., vanEngelsdorp D., Wilkins S., Genersch E. (2013) Standard methods for American foulbrood research. J. Apic. Res., 52(1), DOI 10.3896/IBRA.1.52.1.11

de Guzman, L.I., Frake, A.M. (2007) Temperature affects Aethina tumida (Coleoptera: Nitidulidae) development. J. Apic. Res. 46(2), 88-93

de Guzman, L.I., Rinderer, T.E., Frake, A.M., Tubbs, H., Elzen, P.J., Westervelt, D. (2006) Some observations on the small hive beetle, Aethina tumida Murray in Russian honey bee colonies. Am. Bee. J. 146, 618-620

de Guzman, L.I., Frake, A.M., Rinderer, T.E. (2008) Detection and removal of brood infested with eggs and larvae of small hive beetles (Aethina tumida Murray) by Russian honey bees. J. Apic. Res. Bee. World. 47 (3), 216-221

de Guzman, L.I., Prudente, J., Rinderer, T., Frake, A., Tubbs, H. (2009) Population of small hive beetles (Aethina tumida Murray) in apiaries having different soil textures in Mississippi. Sci. Bee. Cult.. 1, 4-8 
de Guzman, L.I., Frake, A.M., Rinderer, T.E. (2010) Seasonal population dynamics of small hive beetles, Aethina tumida Murray, in the south-eastern USA. J. Apic. Res. Bee. World. 49 (2), 186-191

de Guzman, L.I., Frake, A.M., Rinderer, T.E., Arbogast, R.T. (2011) Effect of Height and Color on the Efficiency of Pole Traps for Aethina tumida (Coleoptera: Nitidulidae). J. Econ. Entomol. 104 (1), 26-31

de Guzman, L.I., Frake, A.M., Rinderer, T.E. (2012) Marking small hive beetles with thoracic notching: effects on longevity, flight ability and fecundity. Apidologie 43 (4), 425-431

Del Valle Molina J.A. (2007) Small hive beetle infestation (Aethina tumida) in Mexico: Immediate notification report. Ref OIE: 6397, Report Date: 26/10/2007

Delaplane, K.S., Ellis, J.D., Hood, W.M. (2010) A test for interactions between Varroa destructor (Acari: Varroidae) and Aethina tumida (Coleoptera: Nitidulidae) in colonies of honey bees (Hymenoptera: Apidae). Ann. Entomol. Soc. Am. 103 (5), 711-715

Donaldson, J.M.I. (1989) Oplostomus fuligineus (Coleoptera: Scarabaeidae): Life Cycle and Biology under Laboratory Conditions, and Its Occurrence in Bee Hives. Coleopt. Bull. 43 (2), 177-182

Downey, D., Chun, S., Follett, P. (2015) Radiobiology of small hive beetle (Coleoptera: Nitidulidae) and prospects for management using sterile insect releases. J. Econ. Entomol. 1-5(2015), 868-872. doi:10.1093/jee/tov068

Dubuc M (2013) Small hive beetle infestation (Aethina tumida), Canada. OIE report, [online] http:// www.oie.int/wahis_2/public/wahid.php/Reviewreport/ Review?page_refer-MapFullEventReport\&reporti$\mathrm{d}=14742$ (Accessed on 10 Jan. 2015)

Duehl, A.J., Arbogast, R.T., Sheridan, A.B., Teal, P.E. (2012) The influence of light on small hive beetle (Aethina tumida) behavior and trap capture. Apidologie 43 (4), 417-424

Ellis, J.D. (2005a) Progress towards controlling small hive beetles with IPM: integrating current treatments. Am. Bee. J. 145 (3), 207-210

Ellis, J.D. (2005b) Progress towards controlling small hive beetles with IPM: knowing our options. Am. Bee. J. 145 (2), 115-119

Ellis, J.D. (2005c) Reviewing the confinement of small hive beetles (Aethina tumida) by western honey bees (Apis mellifera). Bee. World. 86(3), 56-62

Ellis, J.D., Delaplane, K.S. (2006) The effects of habitat type, ApilifeVAR ${ }^{\mathrm{TM}}$, and screened bottom boards on small hive beetle (Aethina tumida) entry into honey bee (Apis mellifera) colonies. Am. Bee. J. 146, 537539

Ellis, J.D., Delaplane, K.S. (2007) The effects of three acaricides on the developmental biology of small hive beetles (Aethina tumida). J. Apic. Res. Bee. World. 46(4), 256-259

Ellis, A., Delaplane, K.S. (2008a) Effects of nest invaders on honey bee (Apis mellifera) pollination efficacy. Agric. Ecosyst. Environ. 127 (3-4), 201-206
Ellis, J.D., Delaplane, K.S. (2008b) Small hive beetle (Aethina tumida) oviposition behaviour in sealed brood cells with notes on the removal of the cell contents by European honey bees (Apis mellifera). J. Apic. Res. Bee. World. 47 (3), 210-215

Ellis, J.D., Hepburn, H.R. (2006) An ecological digest of the small hive beetle (Aethina tumida), a symbiont in honey bee colonies (Apis mellifera). Insect. Soc. 53(1), 8-19

Ellis, J.D., Munn, P.A. (2005) The worldwide health status of honey bees. Bee. World. 86(4), 88-101

Ellis, J.D., Delaplane, K.S., Hepburn, H.R., Elzen, P.J. (2002a) Controlling small hive beetles (Aethina tumida Murray) in honey bee (Apis mellifera) colonies using a modified hive entrance. Am. Bee. J. 142, 288-290

Ellis, J.D., Delaplane, K.S., Hood, W.M. (2002b) Small hive beetle (Aethina tumida Murray) weight, gross biometry, and sex proportion at three locations in the south-eastern United States. Am. Bee. J. 142, 520-522

Ellis, J.D., Neumann, P., Hepburn, H.R., Elzen, P.J. (2002c) Longevity and reproductive success of Aethina tumida (Coleoptera: Nitidulidae) fed different natural diets. J. Econ. Entomol. 95, 902-907

Ellis, J.D., Pirk, C.W.W., Hepburn, H.R., Khastberger, G., Elzen, P.J. (2002d) Small hive beetles survive in honeybee prisons by behavioural mimicry. Naturwissenschaften 89, 326-328

Ellis, J.D., Hepburn, H.R., Delaplane, K., Elzen, P.J. (2003a) A scientific note on small hive beetle (Aethina tumida) oviposition and behaviour during European (Apis mellifera) honey bee clustering and absconding events. J. Apic. Res. 42, 47-48

Ellis, J.D., Hepburn, H.R., Delaplane, K., Neumann, P., Elzen, P.J. (2003b) The effects of adult small hive beetles, Aethina tumida (Coleoptera: Nitidulidae), on nests and flight activity of Cape and European honey bees (Apis mellifera). Apidologie 34, 399-408

Ellis, J.D., Hepburn, H.R., Ellis, A.M., Elzen, P.J. (2003c) Social encapsulation of small hive beetles (Aethina tumida Murray) by European honeybees (Apis mellifera L.). Insect. Soc. 50(3), 286-291

Ellis, J.D., Holland, A.J., Hepburn, H.R., Neumann, P., Elzen, P.J. (2003d) Cape (Apis mellifera capensis) and European (Apis mellifera) honey bee guard age and duration of guarding small hive beetles (Aethina tumida ). J. Apic. Res. 42, 32-34

Ellis, J.D., Richards, C.S., Hepburn, H.R., Elzen, P.J. (2003e) Oviposition by small hive beetles elicits hygienic responses from Cape honeybees. Naturwissenschaften 90, 532-535

Ellis, J.D., Hepburn, R., Elzen, P.J. (2004a) Confinement behavior of cape honey bees (Apis mellifera capensis Esch.) in relation to population densities of small hive beetles (Aethina tumida Murray). J. Insect Behav. 17 (6), 835-842

Ellis, J.D., Delaplane, K.S., Richards, C.S., Hepburn, R., Berry, J.A., Elzen, P.J. (2004b) Hygienic behavior of Cape and European Apis mellifera (Hymenoptera: Apidae) toward Aethina tumida (Coleoptera: 
Nitidulidae) eggs oviposited in sealed bee brood. Ann. Entomol. Soc. Am. 97 (4), 860-864

Ellis, J.D., Hepburn, R., Elzen, P.J. (2004c) Confinement of small hive beetles (Aethina tumida) by Cape honeybees (Apis mellifera capensis). Apidologie 35(4), 389-396

Ellis, J.D., Hepburn, R., Luckman, B., Elzen, P.J. (2004d) Effects of soil type, moisture, and density on pupation success of Aethina tumida (Coleoptera: Nitidulidae). Environ. Entomol. 33 (4), 794-798

Ellis, J.D., Rong, I.H., Hill, M.P., Hepburn, H.R., Elzen, P.J. (2004e) The susceptibility of small hive beetle (Aethina tumida Murray) pupae to fungal pathogens. Am. Bee. J. 144, 486-488

Ellis, J.D., Delaplane, K.S., Cline, A.R., McHugh, J.V. (2008) The association of multiple sap beetle species (Coleoptera: Nitidulidae) with western honey bee (Apis mellifera) colonies in North America. J. Apic. Res. Bee. World. 47 (3), 188-189

Ellis, J.D., Spiewok, S., Delaplane, K.S., Buchholz, S., Neumann, P., Tedders, W.L. (2010) Susceptibility of Aethina tumida (Coleoptera: Nitidulidae) larvae and pupae to entomopathogenic nematodes. J. Econ. Entomol. 103 (1), 1-9

El-Niweiri, M.A., El-Sarrag, M.S., Neumann, P. (2008) Filling the Sudan gap: the northernmost natural distribution limit of small hive beetles. J. Apic. Res. Bee. World. 47 (3), 183-184

Evans, J.D., Spivak, M. (2010) Socialized medicine: Individual and communal disease barriers in honey bees. J. Invertebr. Pathol. 103, S62-S72

Evans, J.D., Pettis, J., Shimanuki, H. (2000) Mitochondrial DNA relationships in an emergent pest of honey bees: Aethina tumida (Coleoptera: Nitidulidae) from the United States and Africa. Ann. Entomol. Soc. Am. 93, $415-420$

Evans, J.D., Pettis, J., Hood, W.M., Shimanuki, H. (2003) Tracking an invasive honey bee pest: mitochondrial DNA variation in North American small hive beetles. Apidologie 34, 103-109

Evans, J.D., Spiewok, S., Teixeira, E.W., Neumann, P. (2008) Microsatellite loci for the small hive beetle, Aethina tumida, a nest parasite of honey bees. Mol. Ecol. Resour. 8(3), 698-700

Eyer, M., Chen, Y.P., Schäfer, M.O., Pettis, J.S., Neumann, P. (2009a) Small hive beetle, Aethina tumida, as a potential biological vector of honeybee viruses. Apidologie 40, 419-428

Eyer, M., Chen, Y.P., Schäfer, M.O., Pettis, J.S., Neumann, P. (2009b) Honey bee sacbrood virus infects adult small hive beetles, Aethina tumida (Coleoptera: Nitidulidae). J. Apic. Res. Bee. World. 48(4), 296-297

FERA (Food and Environment Research Agency) (2010). The Small Hive Beetle: a serious threat to European apiculture. Sand Hutton, UK: Food and Environment Research Agency, 23 pp

FERA (Food and Environment Research Agency) (2014). The small hive beetle a serious threat to European apiculture, $30 \mathrm{pp}$. http://webcache.google usercontent.com/search? q=cache:keg2YYyZe 0J:www.nationalbeeunit.com/ downloadDocument.cfm\%3Fid\%3D17+\&cd=1\&hl=de\&ct $=$ clnk\&gl $=$ de $($ Accessed 10 June 2015)

Fletcher M.J., Cook L.G. (2005) Small hive Beetle. Agnote, NSW-Agriculture, New South Wales. 3 p. http://www.dpi.nsw.gov.au/_data/assets/pdf_file/ 0003/117372/small-hive-beetle.pdf (Accessed 11 June 2015)

Frake, A.M., De Guzman, L.I., Rinderer, T.E. (2009) Comparative resistance of Russian and Italian honey bees (Hymenoptera: Apidae) to small hive beetles (Coleoptera: Nitidulidae). J. Econ. Entomol. 102 (1), 13-19

Freeman, J. (2009) Things we need to know about small hive beetles. Am. Bee. J. 149, 947-949

Gillespie, P., Staples, J., King, C., Fletcher, M.J., Dominiak, B.C. (2003) Small hive beetle, Aethina tumida (Murray) (Coleoptera: Nitidulidae) in New South Wales. Gen. Appl. Entomol. 32, 5-8

Giovenazzo, P., Bernier, M. (2015) Situation du petit coléoptère de la ruche au Québec. L'Abeille. 37 (2), 8-9

Giovenazzo, P., Boucher, C. (2010) A scientific note on the occurrence of the small hive beetle (Aethina tumida Murray) in Southern Quebec. Am. Bee. J. 150, 275276

Gordon, R., Bresolin-Schott, N., East, I.J. (2014) Nomadic beekeeper movements create the potential for widespread disease in the honeybee industry. Aust. Vet. J. 92, 283-290

Graham J. (2009) The attraction of bumble bee (Hymenoptera: Apidae, Bombus impatiens Cresson) colonies to small hive beetles (Coleoptera: Nitidulidae, Aethina tumida Murray). $\mathrm{PhD}$ thesis, University of Florida, USA

Graham, J., Ellis, J.D., Carroll, M.J., Teal, P.E. (2011a) Aethina tumida (Coleoptera: Nitidulidae) attraction to volatiles produced by Apis mellifera (Hymenoptera: Apidae) and Bombus impatiens (Hymenoptera: Apidae) colonies. Apidologie 42 (3), 326-336

Graham, J., Ellis, J.D., Benda, N.D., Kurtzman, C.P., Boucias, D.G. (2011b) Kodamaea ohmeri (Ascomycota: Saccharomycotina) presence in commercial Bombus impatiens Cresson and feral Bombus pensylvanicus DeGeer (Hymenoptera: Apidae) colonies. J. Apic. Res. 50 (3), 218-226

Greco, M.K., Hoffmann, D., Dollin, A., Duncan, M., Spooner-Hart, R., Neumann, P. (2010) The alternative Pharaoh approach: stingless bees mummify beetle parasites alive. Naturwissenschaften 97 (3), 319-323

Gutierrez M.R. (2014) Small hive beetle infestation (Aethina tumida), Nicaragua. OIE report, [online] http://www.oie.int/wahis_2/public/wahid.php/ $\mathrm{R}$ e vi e w r e p o r t T

Review?page_refer=MapFullEventReport\&reporti$\mathrm{d}=14888$ (Accessed on 20 May 2015)

Habeck, D.H. (2002) Nitidulidae. In: Arnett, R.H., Thomas, M.C., Skelley, P.E., Frank, J.H. (eds.) American Beetles, vol. 2, pp. 311-315. CRC Press, Boca Raton

Haddad, N., Esser, J., Neumann, P. (2008) Association of Cryptophagus hexagonalis (Coleoptera: 
Cryptophagidae) with honey bee colonies (Apis mellifera ). J. Apic. Res. 47, 189-190

Halcroft, M., Spooner-Hart, R., Neumann, P. (2008) A noninvasive and non-destructive method for observing inhive behaviour of the Australian stingless bee, Austroplebeia australis. J. Apic. Res. 47, 82-83

Halcroft, M., Spooner-Hart, R., Neumann, P. (2011) Behavioral defense strategies of the stingless bee, Austroplebeia australis, against the small hive beetle, Aethina tumida . Insect. Soc. 58(2), 245-253

Haque, N.M.M., Levot, G.W. (2005) An improved method of laboratory rearing the small hive beetle Aethina tumida Murray (Coleoptera: Nitidulidae). Gen. Appl. Entomol. 34, 29-30

Harman A. (2005) Small hive beetle. Bee. Cult. (June), 3941

Hassan, A.R., Neumann, P. (2008) A survey for the small hive beetle in Egypt. J. Apic. Res. Bee. World. 47 (3), 185-186

Hayes, R.A., Rice, S.J., Amos, B.A., Leemon, D.M. (2015) Increased attractiveness of honeybee hive product volatiles to adult small hive beetle, Aethina tumida, resulting from small hive beetle larval infestation. Entomol. Exp. Appl. 155, 240-248

Hepburn, H.R., Radloff, S.E. (1998) Honeybees of Africa. Springer Verlag, Berlin

Hepburn, H.R., Reece, S., Neumann, P., Moritz, R.F.A., Radloff, S.E. (1999) Absconding in honeybees (Apis mellifera) in relation to queen status and mode of reproduction. Insect. Soc. 46, 323-326

Hoffmann, D., Pettis, J.S., Neumann, P. (2008) Potential host shift of the small hive beetle (Aethina tumida) to bumblebee colonies (Bombus impatiens). Insect. Soc. $\mathbf{5 5}, 153-162$

Hood, W.M. (2000) Overview of the small hive beetle Aethina tumida in North America. Bee. World. 81, 129-137

Hood, W.M. (2004) The small hive beetle, Aethina tumida : a review. Bee. World. 85(3), 51-59

Hood, W.M. (2006) Evaluation of two small hive beetle traps in honey bee colonies. Am. Bee. J. 146, 873-876

Hood, W.M. (2009) Risk of feeding honey bee colonies pollen substitute patties in winter when small hive beetles, Aethina tumida Murray (Coleoptera: Nitidulidae) are present. Sci. Bee. Cult.. 1 (1), 13-15

Hood W.M. (2011). Handbook of Small Hive Beetle IPM. Clemson University, Cooperative Extension Service. Extension Bulletin 160, pp. 20. http:// www.extension.org/sites/default/files/ Handbook of Small Hive Beetle IPM.pdf(accessed 10 June 2015)

Hood, W.M., Miller, G.A. (2005) Evaluation of an upper hive entrance for control of small hive beetles (Coleoptera: Nitidulidae) in colonies of honey bees (Hymenoptera: Apidae). J. Econ. Entomol. 98 (6), 1791-1795

Horridge, M., Madden, J., Wittwer, G. (2005) The impact of the 2002-2003 drought on Australia. J. Policy Model 27, 285-308
Ibler, B. (2013) On biology and Evolution of Longevity in Animals. Zool. Garten. 82 (1-2), 72-95

Jacobson, S. (2005) Will the small hive beetle become a problem outside the South? Am. Bee. J. 145, 743-746

James, D.G., Faulder, R.J., Vogele, B., Moore, C.J. (2000) Pheromone-trapping of Carpophilus spp. (Coleoptera: Nitidulidae) in stone fruit orchards near Gosford, New South Wales: Fauna, seasonality and effect of insecticides. Aust. J. Entomol. 39, 310-315

Kanga, L.H.B., Somorin, A.B. (2011) Susceptibility of the small hive beetle, Aethina tumida (Coleoptera: Nitidulidae), to insecticides and insect growth regulators. Apidologie 43 (1), 95-102

Keller J.J. (2002) Testing effects of alternative diets on reproduction rates of the small hive beetle, Aethina tumida. MSc thesis, University of Raleigh, USA

Keshlaf, M., Spooner-Hart, R. (2013) Evaluation of antiVarroa bottom boards to control small hive beetle (Aethina tumida). Intern. J. Biol. Food. Vet. Agric. Engine. 7(12), 809-811

Kirejtshuk, A.G. (1994a) System, evolution of mode of life, and phylogeny of the order Coleoptera. I. Entomol. Obozr. 73 (2), 266-288

Kirejtshuk, A.G. (1994b) System, evolution of mode of life, and phylogeny of the order Coleoptera. II. Entomol. Rev. 76 (1), 1-20

Kirejtshuk, A.G. (1997) On the evolution of anthophilous Nitidulidae (Coleoptera) in tropical and subtropical regions. Bonn. Zool. Beitr. 47, 111-134

Kirejtshuk, A.G., Lawrence, J.F. (1999) Notes on the Aethina complex (Coleoptera: Nitidulidae: Nitidulinae), with a review of Aethina (Cleidorura) subgen. nov. and Aethina (Idaethina) Gemminger et Harold. Ann Zool 49 (3), 233-254

Kollmann, M., Rupenthal, A., Neumann, P., Huetteroth, W., Schachtner, J. (2015) Novel antennal lobe substructures revealed in the small hive beetle, Aethina tumida. Cell Tissue Res. . doi:10.1007/s00441-015-2282-9

Kozak, P. (2010) Small Hive Beetle. Guelph, , p. 4. Ontario Ministry of Agriculture, Food and Rural Affairs, Ontario

Krishnan, K., Neumann, P., Ahmad, A.H., Pimid, M. (2015) A scientific note on the association of Haptoncus luteolus (Coleoptera: Nitidulidae) with colonies of multiple stingless bee species. Apidologie 46, 262-264

Kronauer, D.J.C. (2009) Recent advances in army ant biology (Hymenoptera: Formicidae). Myrmecol. News. 12, 51-65

Kugonza, D.R., Kamatara, K.B., Nabakabya, D., Kikonyogo, S. (2009) Effects of hive type and tree shade on colonization rate and pest prevalence of honeybee (Apis mellifera) colonies in Central Uganda. Afr. J. Anim. Biomed. Sci. 4(2), 87-92

Lawal, O.A., Banjo, A.D. (2007) A checklist of pests and visitors of Apis mellifera adansonii in the six states of south-western Nigeria. Apiacta 42, 39-63

Lawal, O.A., Banjo, A.D. (2008) Seasonal variations of pests and parasites associated with honeybees (Apis 
mellifera adansonii ) in Southwestern Nigeria. Acad. J. Entomol. 1(1), 01-06

Leemon D. (2012) In-hive fungal biocontrol of small hive beetle. Rural Industries Research and Development Corporation Publication no. 12/012. https:// rirdc.infoservices.com.au/items/12-012 (Accessed 14 June 2015)

Leemon D., McMahon J. (2009) Feasibility study into inhive fungal bio-control of small hive beetle. Rural Industries Research and Development Corporation Publication no. 09/090. https:// rirdc.infoservices.com.au/items/09-090 (Accessed 14 June 2015)

Levot, G.W. (2008) An insecticidal refuge trap to control adult small hive beetle, Aethina tumida Murray (Coleoptera: Nitidulidae) in honey bee colonies. J. Apic. Res. Bee. World. 47 (3), 222-228

Levot G.W. (2012) Commercialisation of the Small Hive Beetle Harbourage Device. Rural Industries Research and Development Corporation Publication no. 11/122. (Accessed 06 November 2015)

Levot, G.W., Somerville, D. (2012) Efficacy and safety of the insecticidal small hive beetle refuge trap APITHOR $^{\mathrm{TM}}$ in bee hives. Aust. J. Entomol. 51, 198-204

Lin, H.C., Phelan, P.L., Bartelt, R.J. (1992) Synergism between synthetic food odours and the aggregation pheromone for attracting Carpophilus lugubris in the field. Environ. Entomol. 21, 156-159

Lounsberry, Z., Spiewok, S., Pernal, S.F., Sonstegard, T.S., Hood, W.M., Pettis, J., Neumann, P., Evans, J.D. (2010) Worldwide diaspora of Aethina tumida (Coleoptera: Nitidulidae), a nest parasite of honey bees. Ann. Entomol. Soc. Am. 103 (4), 671-677

Loza L.M.S., Álvarez L.G.L., Ugalde J.A.G. (2014) Manual: Neuvos manejesos en la apicultura para el control del pequeño escarabajo de la colmena. SAGARPA, [online] http://www.sagarpa.gob.mx/ganaderia/Docu$\mathrm{m}$ e $\mathrm{n} \mathrm{t} \mathrm{s} \mathrm{/}$ final $\% 20$ MANUAL $\% 202$ da $\% 20$ EDICI $\%$ C3\%93N.pdf (Accessed on 10 May 2015)

Lundie A.E. (1940) The small hive beetle Aethina tumida, Science Bulletin 220, Department of Agriculture and Forestry, Government Printer, Pretoria, South Africa

Lundie, A.E. (1952) The principal diseases and enemies of honey bees. S. Afr. Bee. J. 27, 9

Martin, S. (2013) Double trouble in paradise: small hive beetle joins Varroa in Hawaii. Am. Bee. J. 153 (5), 529-532

Meikle, W.G., Diaz, R. (2012) Factors affecting pupation success of the small hive beetle, Aethina tumida. J. Insect Sci. 12 (118), 1-9

Meikle, W.G., Patt, J.M. (2011) The Effects of Temperature, Diet, and Other Factors on Development, Survivorship, and Oviposition of Aethina tumida (Coleoptera: Nitidulidae). J. Econ. Entomol. 104(3), 753-763

Meikle, W.G., Patt, J.M., Sammataro, D. (2012) Intraspecific Competition Effects on Aethina tumida (Coleoptera: Nitidulidae). J. Econ. Entomol. 105(1), 26-33
Meikle W.G., Holst N., Cook S.C., Patt J.N. (2015) Variability in small hive beetle (Coleoptera: Nitidulidae) reproduction in laboratory and field experiments, J. Econ. Entomol., online first, 1-7; DOI: 10.1093/jee/ tov 101

Mensah G.A., Pomalegni S.C.B., Goergen G., Ekue M.R.M., Balagoun B., Hounha J.M., Ogouma A.E.E. (2007) Aethina tumida (Murray 1867), un coléoptère déprédateur des abeilles et des produits de la ruche dans les exploitations apicoles installées au Nord-Est du Bénin, http://www.slire.net/download/299/ poster_col_opt_res_abeilles.pdf (Accessed 12 May 2015)

Michener, C.D. (1974) The social behaviour of the bees. Harvard University Press, Cambridge

Michener, C.D. (2000) The bees of the world. The Johns Hopkins University Press, Baltimore

Milián J.L. (2012) Reporte de notificación de Aethina tumida a la OIE. Dirección del Instituto de Medicina Veterinaria, Ministerio de la Agricultura, La Habana, Cuba

Minister for Agriculture (2002) Small hive beetle confirmed in Sydney bee apiary: Amery, Agricult. media releases 31 October 2002, [online] http:// minister.agric.nsw.gov.au/reader/16058 (Accessed on 10 May 2015)

Morse, R.A., Nowogrodzki, R. (1990) Honey bee pests, predators, and diseases, p. 474. Comstock, Ithaca

Mostafa, A.M., Williams, R.N. (2000) New record of the small hive beetle in Egypt and notes on its distribution and control. Bee. World. 83, 99-108

M'Peindagha Bongho F.A. (2009) Inventaire des insectes nuisibles au développement des colonies d'abeilles, Apis mellifera adansonii Latreille dans la région de Carango au Burkina Faso. Diplom d'ingénieur du développement rural. No: 00-2009/(E\&F). Université polytechnique de Bobo-Dioulasso

Muerrle, T.M., Neumann, P., Dames, J.F., Hepburn, H.R., Hill, M.P. (2006) Susceptibility of adult Aethina tumida (Coleoptera: Nitidulidae) to entomopathogenic fungi. J. Econ. Entomol. 99(1), 1-6

Mulherin T. (2009) Stepping up the small hive beetle battle. Minister for Primary Industries, Fisheries and Rural and Regional Queensland, Queensland Government, [online] http://statements.cabinet.qld.gov.au/MMS/ StatementDisplaySingle.aspx $? \mathrm{id}=66217$ (Accessed on 10 May 2015)

Mullin, C.A., Frazier, M., Frazier, J.L., Ashcraft, S., Simonds, R., vanEngelsdorp, D., Pettis, J.S. (2010) High Levels of Miticides and Agrochemicals in North American Apiaries: Implications for Honey Bee Health. PLoS ONE 5(3), e9754. doi:10.1371/ journal.pone.0009754

Murilhas, A.M. (2004) Aethina tumida arrives in Portugal. Will it be eradicated? EurBee Newslett 2, 7-9

Mürrle, T., Neumann, P. (2004) Mass production of small hive beetles (Aethina tumida, Coleoptera: Nitidulidae). J. Apic. Res. 43 (2), 144-145

Mustafa S. (2015) Reproduktionsbiologie und olfaktorisches Verhalten des Kleinen Beutenkäfers 
Aethina tumida Murray 1867 (Nitidulidae). PhD thesis, University of Hohenheim, Germany

Mustafa S., Rosenkranz P., Tolasch T., Steidle H. (2006) Chemotactic orientation of the small hive beetle (Aethina tumida, Nitidulidae) in laboratory bioassays, in: Proceedings of the $2^{\text {nd }}$ European Conference of Apidology EurBee, Prague (Czech Republic), 10-16 September 2006, (Eds. Vladimir Vesely, Marcela Vořechovská and Dalibor Titěra), Bee Research Institute Dol, CZ, p. 47

Mustafa, S.G., Spiewok, S., Duncan, M., Spooner-Hart, R., Rosenkranz, P. (2014) Susceptibility of small honey bee colonies to invasion by the small hive beetle, Aethina tumida (Coleoptera, Nitidulidae). J. Appl. Entomol. 138(7), 547-550

Mutinelli, F. (2014) The 2014 Outbreak Of Small Hive Beetle In Italy. Bee. World. 91 (4), 88-89

Mutinelli, F., Montarsi, F., Federico, G., Granato, A., Ponti, A.M., Grandinetti, G., Chauzat, M.P. (2014) Detection of Aethina tumida Murray (Coleoptera: Nitidulidae.) in Italy: outbreaks and early reaction measures. J. Apic. Res. 53 (5), 569-575

Mutsaers M. (2006) Beekeepers observations on the small hive beetle (Aethina tumida) and other pests in bee colonies in West and East Africa, in: Proceedings of the $2^{\text {nd }}$ European Conference of Apidology EurBee, Prague (Czech Republic), 10-16 September 2006, (Eds. Vladimir Vesely, Marcela Vořechovská and Dalibor Titěra), Bee Research Institute Dol, CZ, p. 44

Nentwig, W. (2007) Biological invasions. Springer Verlag, Berlin Heidelberg

Neumann, P. (2016) Small hive beetle in Italy: what can we expect in the future? In: Carreck, N.L. (ed.) The small hive beetle in Europe. International Bee Research Association, Groombridge

Neumann, P., Ellis, J.D. (2008) The small hive beetle (Aethina tumida Murray, Coleoptera: Nitidulidae): distribution, biology and control of an invasive species. J. Apic. Res. Bee. World. 47 (3), 180-183

Neumann, P., Elzen, P.J. (2004) The biology of the small hive beetle (Aethina tumida, Coleoptera: Nitidulidae): Gaps in our knowledge of an invasive species. Apidologie 35, 229-247

Neumann, P., Härtel, S. (2004) Removal of small hive beetle (Aethina tumida) eggs and larvae by African honeybee colonies (Apis mellifera scutellata). Apidologie 35, 31-36

Neumann, P., Hepburn, H.R. (2011) Absconding and colony mergers of orphaned Cape honeybees (Apis mellifera capensis ). J. Apic. Res. 50, 165-166

Neumann, P., Hoffmann, D. (2008) Small hive beetle diagnosis and control in naturally infested honeybee colonies using bottom board traps and CheckMite + strips. J. Pest. Sci. 81, 43-48

Neumann, P., Ritter, W. (2004) A scientific note on the association of Cychramus luteus (Coleoptera: Nitidulidae) with honeybee (Apis mellifera) colonies. Apidologie 35, 665-666
Neumann, P., Pirk, C.W.W., Hepburn, H.R., Elzen, P.J., Baxter, J.R. (2001a) Laboratory rearing of small hive beetles Aethina tumida (Coleoptera: Nitidulidae). J. Apic. Res. 40, 111-112

Neumann P., Buchholz S., Jenkins M., Pettis J.S. (2016a) The suitability of sterile insect technique as a pest management of small hive beetles, Aethina tumida Murray (Coleoptera: Nitidulidae). J. Apic. Res., in press. doi:10.1080/00218839.2016.1142734

Neumann, P., Pirk, C.W.W., Hepburn, H.R., Solbrig, A.J., Ratnieks, F.L.W., Elzen, P.J., Baxter, J.R. (2001b) Social encapsulation of beetle parasites by Cape honeybee colonies (Apis mellifera capensis Esch.). Naturwissenschaften 88, 214-216

Neumann, P., Pirk, C.W.W., Hepburn, H.R., Radloff, S.E. (2001c) A scientific note on the natural merger of two honeybee colonies (Apis mellifera capensis). Apidologie 32, 113-114

Neumann, P., Hoffmann, D., Duncan, M., Spooner-Hart, R. (2010) High and rapid infestation of isolated commercial honey bee colonies with small hive beetles in Australia. J. Apic. Res. Bee. World. 49(4), 343-344

Neumann, P., Hoffmann, D., Duncan, M., Spooner-Hart, R., Pettis, J.S. (2012) Long-range dispersal of small hive beetles. J. Apic. Res. 51 (2), 214-215

Neumann, P., Evans, J.D., Pettis, J.S., Pirk, C.W.W., Schäfer, M.O., Tanner, G., Ellis, J.D. (2013) Standard methods for small hive beetle research. J. Apic. Res. 52 (4), 1-32

Neumann P., Naef J., Crailsheim K., Crewe R.M., Pirk C.W.W. (2015) Hit-and-run trophallaxis of small hive beetles. Ecol. Evol. doi: 10.1002/ece3.1806/full

Neumann P., Merkel K., Pettis J.S., Pirk C.W.W. (2016b) European honeybees can be more aggressive toward the small hive beetle, Aethina tumida, compared to African ones. J. Apic. Res., in review

Nolan, M.P., Hood, M. (2008) Comparison of two attractants to small hive beetles, Aethina tumida, in honey bee colonies. J. Apic. Res. Bee. World. 47 (3), 229-233

Nolan, M.P., Hood, M. (2010) Trapping small hive beetle in honey supers and brood chambers of honey bee colonies. Sci. Bee. Cult.. 2(1), 8-11

Palmeri, V., Scrito, G., Malacrino, A., Laudani, F., Campolo, O. (2015) A scientific note on a new pest for European honey bees: first report of Aethina tumida (Coleoptera Nitidulidae) in Italy. Apidologie 46(4), 527-529

Park, M.S., Fong, J.J., Lee, H., Shin, S., Lee, S., Lee, N., Lima, Y.W. (2014) Determination of coleopteran insects associated with spore dispersal of Cryptoporus volvatus (Polyporaceae: Basidiomycota) in Korea. J. Asia. Pac. Entomol. 17, 647-651

Peña, W.L., Carballo, L.F., Lorenzo, J.D. (2014) Reporte de Aethina tumida Murray (Coleoptera, Nitidulidae) en colonias de la abeja sin aguijón Melipona beecheii Bennett de Matanzas y Mayabeque. Rev. Salud. Anim. 36 (3), 201-204

Petroski, R.J., Bartelt, R.J., Vetter, R.S. (1994) Maleproduced aggregation pheromone of Carpophilus 
obsoletus (Coleoptera, Nitidulidae). J. Chem. Ecol. 20, 1483-1493

Pettis, J., Shimanuki, H. (2000) Observations on the small hive beetle, Aethina tumida, Murray, in the United States. Am. Bee. J. 140, 152-155

Pettis, J., Martin, D., vanEngelsdorp, E. (2014) Migratory Beekeeping. In: Ritter, W. (ed.) Bee Health and Veterinarians, pp. 51-54. OIE, Paris

Pirk, C.W.W., Neumann, P. (2013) Small hive beetles are facultative predators of adult honey bees. J. Insect Behav. 26, 796-803

Pirk, C.W.W., Yusuf, A.A. (2015) A small hive beetle lesson from South Africa. In: Carreck, N.L. (ed.) The small hive beetle in Europe. International Bee Research Association, Groombridge

Ramírez, M., Calderón, R.A., Hernández, P., Benítez, J. (2014) Presencia del pequeño escarabajo de la colmena, Aethina tumida, en colmenas de abejas africanizadas en Centroamérica. Bol. Parasitol. 15(3), $1-2$

Rasolofoarivao, H., Clemencet, J., Ravaomanarivo, L.H.R., Razafindrazaka, D., Reynaud, B., Delatte, H. (2013) Spread and strain determination of Varroa destructor (Acari: Varroidae) in Madagascar since its first report in 2010. Exp. Appl. Acarol. 60, 521-530

Rhodes J., McCorkell B. (2007) Small hive beetle Aethina tumida in New South Wales apiaries 2002-6: survey results 2006. New South Wales Department of Primary Industry. 1-32. http://www.dpi.nsw.gov.au/_data/assets/pdf_fi le/0005/167378/Small-Hive-BeetleAethina-tumida-in-New-South-Wales-Apiaries-20026-Survey-Results-2006.pdf (Accessed 10.06.2015)

Richards, C.S., Hill, M.P., Dames, J.F. (2005) The susceptibility of small hive beetle (Aethina tumida Murray) pupae to Aspergillus niger (van Tieghem) and $A$. flavus (Link: Grey). Am. Bee. J. 145, 748-751

Rivera-Marchand, B., Oskay, D., Giray, T. (2012) Gentle Africanized bees on an oceanic island. Evol. Appl. 5, 746-756

Robson J.D. (2012) Small Hive Beetle Aethina tumida Murray (Coleoptera: Nitidulidae), Pest Alert 12-01. PLANT PEST CONTROL BRANCH, Division of Plant Industry, Department of Agriculture First Issued January 20121428 South King Street, Honolulu, Hawaii 96814, [online] http://hdoa.hawaii.gov/pi/files/ 2013/01/NPA-SHB-1-12.pdf (Accessed on 10.05.2015)

Sanford, M.T. (1998) Aethina tumida : a new beehive pest in the Western hemisphere. Apis 16, 1-5

Santino, I., Bono, S., Borruso, L., Bove, M., Cialdi, E., Martinelli, D., Alari, A. (2013) Kodamaea ohmeri isolate from two immunocompromised patients: first report in Italy. Mycoses 56, 179-181

Schäfer, M., Ritter, W. (2014) The small hive beetle (Aethina tumida). In: Ritter, W. (ed.) Bee health and veterinarians, pp. 149-156. World Organisation for Animal Health, Paris

Schäfer, M.O., Pettis, J.S., Ritter, W., Neumann, P. (2008) A scientific note on quantitative diagnosis of small hive beetles, Aethina tumida, in the field. Apidologie 39 (5), 564-565

Schäfer, M.O., Ritter, W., Pettis, J.S., Teal, P.E., Neumann, P. (2009) Effects of organic acid treatments on small hive beetles, Aethina tumida, and the associated yeast Kodamaea ohmeri. J. Pest. Sci. 82 (3), 283-287

Schäfer, M.O., Pettis, J.S., Ritter, W., Neumann, P. (2010a) Simple small hive beetle diagnosis. Am. Bee. J. 150, 371-372

Schäfer, M.O., Ritter, W., Pettis, J.S., Neumann, P. (2010b) Small hive beetles, Aethina tumida, are vectors of Paenibacillus larvae. Apidologie 41 (1), 14-20

Schäfer, M.O., Ritter, W., Pettis, J.S., Neumann, P. (2010c) Winter losses of honeybee colonies (Hymenoptera: Apidae): The role of infestations with Aethina tumida (Coleoptera: Nitidulidae) and Varroa destructor (Parasitiformes: Varroidae). J. Econ. Entomol. 103 (1), 10-16

Schäfer, M.O., Ritter, W., Pettis, J.S., Neumann, P. (2011) Concurrent parasitism alters thermoregulation in honey bee (Hymenoptera: Apidae) winter clusters. Ann. Entomol. Soc. Am. 104 (3), 476-482

Schmid-Hempel, P. (2005) Evolutionary ecology of insect immune defences. Ann. Rev. Entomol. 50 , 529-551

Schmolke, M.D. (1974) A study of Aethina tumida: the small Hive Beetle, p. 178. University of Rhodesia, Rhodesia. Project Report

Shapiro-Ilan, D.I., Morales-Ramos, J.A., Rojas, M.G., Tedders, W.L. (2010) Effects of a novel entomopathogenic nematode-infected host formulation on cadaver integrity, nematode yield, and suppression of Diaprepes abbreviatus and Aethina tumida. J. Invertebr. Pathol. 103 (2), 103-108

Solbrig A.J. (2001) Interactions between the South African honeybee Apis mellifera capensis Esch. and the small hive beetle Aethina tumida. MSc thesis FU Berlin

Somerville, D. (2003). Study of the Small Hive Beetle in the U.S.A. In RIRDC Publication No. 03/050., 57 Barton, ACT, Australia: Rural Industries Research and Development Corporation

Spiewok, S., Neumann, P. (2006a) Cryptic low-level reproduction of small hive beetles in honeybee colonies. J. Apic. Res. 45(1), 47-48

Spiewok, S., Neumann, P. (2006b) Infestation of commercial bumblebee (Bombus impatiens) field colonies by small hive beetles (Aethina tumida). Ecol. Entomol. 31, 623-628

Spiewok, S., Neumann, P. (2006c) The impact of recent queenloss and colony phenotype on the removal of Small hive beetle (Aethina tumida Murray) eggs and larvae by African honeybee colonies (Apis mellifera capensis Esch.). J. Insect Behav. 19(5), 601-611

Spiewok, S., Neumann, P. (2012) Sex ratio and dispersal of small hive beetles. J. Apic. Res. 51 (2), 216-217

Spiewok, S., Neumann, P., Hepburn, H.R. (2006a) Preparation for disturbance-induced absconding of Cape honeybee colonies (Apis mellifera capensis Esch.). Insect. Soc. 53, 27-31 
Spiewok S., Neumann P., Radloff S.E. (2006b) Forensics of abandoned honeybee nests: reproduction of small hive beetles (Aethina tumida) and greater wax moths (Galleria monella), in: Proceedings of the $2^{\text {nd }}$ European Conference of Apidology EurBee, Prague (Czech Republic), 10-16 September 2006, (Eds. Vladimir Vesely, Marcela Vořechovská and Dalibor Titěra), Bee Research Institute Dol, CZ, ISBN 978-80903442-6-6, p. 43

Spiewok, S., Pettis, J.S., Duncan, M., Spooner-Hart, R., Westervelt, D., Neumann, P. (2007) Small hive beetle, Aethina tumida, populations I: Infestation levels of honeybee colonies, apiaries and regions. Apidologie 38 (6), 595-605

Spiewok, S., Duncan, M., Spooner-Hart, R., Pettis, J.S., Neumann, P. (2008) Small hive beetle, Aethina tumida, populations II: Dispersal of small hive beetles. Apidologie 39(6), 683-693

Spooner-Hart, R., Annand, N., Duncan, M. (2016) The small hive beetle in Australia. In: Carreck, N.L. (ed.) The small hive beetle in Europe. International Bee Research Association, Groombridge

Spreafico, M., Eördegh, F.R., Bernadinelli, I., Colombo, M. (2001) First detection of strains of Varroa destructor resistant to coumaphos. Results of the laboratory test trials. Apidologie 32, 49-55

Stedman M. (2006) Small hive beetle (SHB): Aethina tumida Murray (Coleoptera: Nitidulidae). Fact Sheet 03/06, Primary Industries and Resources South Australia, http://www.pir.sa.gov.au/_ data/assets/pdf_file/ 0015/41262/apiary_shb_fact_sheet_2006.pdf (Accessed on 1106 2015)

Strauss, U., Human, H., Crewe, R.M., Pirk, C.W.W. (2010) The first report of storage mites Caloglyphus hughesi (Acaridae) on laboratory-reared Aethina tumida Murray (Coleoptera: Nitidulidae) in South Africa. Afr. Entomol. 18(2), 379-382

Strauss, U., Human, H., Gauthier, L., Crewe, R.M., Dietemann, V., Pirk, C.W. (2013) Seasonal prevalence of pathogens and parasites in the savannah honeybee (Apis mellifera scutellata). J. Invertebr. Pathol. 114(1), 45-52

Torchin M.E., Lafferty K.D., McKenzie V.J., Kuris A.M. (2003) Introduced species and their missing parasites. Nature 421, 628-630

Torto, B., Suazo, A., Alborn, H., Tumlinson, J.H., Teal, P.E. (2005) Response of the small hive beetle (Aethina tumida ) to a blend of chemicals identified from honeybee (Apis mellifera) volatiles. Apidologie 36(4), 523-532

Torto, B., Arbogast, R.T., Alborn, H., Suazo, A., Van Engelsdorp, D., Boucias, D., Tumlinson, J.H., Teal, P.E. (2007a) Composition of volatiles from fermenting pollen dough and attractiveness to the small hive beetle Aethina tumida, a parasite of the honeybee Apis mellifera. Apidologie 38(4), 380-389

Torto, B., Arbogast, R.T., Van Engelsdorp, D., Williams, S., Purcell, D., Boucias, D., Tumlinson, J.H., Teal, P.E. (2007b) Trapping of Aethina tumida Murray
(Coleoptera: Nitidulidae) from Apis mellifera L. (Hymenoptera: Apidae) colonies with an in-hive baited trap. Environ. Entomol. 36(5), 1018-1024

Torto, B., Boucias, D.G., Arbogast, R.T., Tumlinson, J.H., Teal, P.E.A. (2007c) Multitrophic interaction facilitates parasite-host relationship between an invasive beetle and the honey bee. PNAS 104 (20), 8374-8378

Torto, B., Fombong, A.T., Arbogast, R.T., Teal, P.E. (2010a) Monitoring Aethina tumida (Coleoptera: Nitidulidae) with baited bottom board traps: occurrence and seasonal abundance in honey bee colonies in Kenya. Environ. Entomol. 39(6), 1731-1736

Torto, B., Fombong, A.T., Mutyambai, D.M., Muli, E., Arbogast, R.T., Teal, P.E. (2010b) Aethina tumida (Coleoptera: Nitidulidae) and Oplostomus haroldi (Coleoptera: Scarabaeidae): occurrence in Kenya, distribution within honey bee colonies, and responses to host odors. Ann. Entomol. Soc. Am. 103 (3), 389-396

Valério da Silva, M.J. (2014) The first report of Aethina tumida in the European Union, Portugal 2004. Bee. World. 91 (4), 90-91

Van Engelsdorp, D., Underwood, R., Caron, D., Hayes, J. (2007) An estimate of managed colony losses in the winter of 2006-2007: A report commissioned by the apiary inspectors of America. Am. Bee. J. 147, 599603

Istituto Zooprofilattico Sperimentale delle Venezie (2015) Aethina tumida in Italy: updates. http:// www.izsvenezie.com/aethina-tumida-in-italy/ (Accessed 03 Nov 2015)

Villa, J.D. (2004) Swarming behavior of honey bees (Hymenoptera: Apidae) in Southeastern Louisiana. Ann. Entomol. Soc. Am. 97 (1), 111-116

Wade R. (2012) Keeping out small hive beetles, Aussie Bee Online Article 18, [online] http:// www.aussiebee.com.au/aussiebeeonline018.pdf. (Accessed on 10 May 2015)

Ward, L., Brown, M., Neumann, P., Wilkins, S., Pettis, J., Boonham, N. (2007) A DNA method for screening hive debris for the presence of small hive beetle (Aethina tumida). Apidologie 38 (3), 272-280

Westervelt, D. (2005) Small hive beetles in the USA - What we've learned in nine years. Am. Bee. J. 145(10), 805-807

Westervelt, D., Causey, D., Neumann, P., Ellis, J.D., Hepburn, H.R. (2001) Grease patties worsen small hive beetle infestations. Am. Bee. J. 141, 775

Williams-Guillén, K., Perfecto, I., Vandermeer, J. (2008) Bats Limit Insects in a Neotropical Agroforestry System. Science $\mathbf{3 2 0}, 70$

Wright, N., Steinkraus, D. (2013) A scientific note on a protozoan pathogen of the small hive beetle. Apidologie 44, 173-175

Yang, M., Radloff, S., Tan, K., Hepburn, R. (2010) Antipredator fan-blowing in guard bees, Apis mellifera capensis Esch. J. Insect Behav. 23 (1), 12-18

Zacchetti, F. (2015) Aethina tumida dal vivo. L'Apis. 2, 58 